\title{
Nerve Growth Factor Sensitizes Adult Sympathetic Neurons to the Proinflammatory Peptide Bradykinin
}

\author{
Oscar Vivas, ${ }^{\star}$ Martin Kruse, ${ }^{\star}$ and Bertil Hille \\ Department of Physiology and Biophysics, University of Washington, Seattle, Washington 98195
}

Levels of nerve growth factor (NGF) are elevated in inflamed tissues. In sensory neurons, increases in NGF augment neuronal sensitivity (sensitization) to noxious stimuli. Here, we hypothesized that NGF also sensitizes sympathetic neurons to proinflammatory stimuli. We cultured superior cervical ganglion (SCG) neurons from adult male Sprague Dawley rats with or without added NGF and compared their responsiveness to bradykinin, a proinflammatory peptide. The NGF-cultured neurons exhibited significant depolarization, bursts of action potentials, and $\mathrm{Ca}^{2+}$ elevations after bradykinin application, whereas neurons cultured without NGF showed only slight changes in membrane potential and cytoplasmic $\mathrm{Ca}^{2+}$ levels. The NGF effect, which requires trkA receptors, takes hours to develop and days to reverse. We addressed the ionic mechanisms underlying this sensitization. NGF did not alter bradykinin-induced M-current inhibition or phosphatidylinositol 4,5-bisphosphate hydrolysis. Maxi-K channel-mediated current evoked by depolarizations was reduced by $50 \%$ by culturing neurons in NGF. Application of iberiotoxin or paxilline, blockers of Maxi-K channels, mimicked NGF treatment and sensitized neurons to bradykinin application. A calcium channel blocker also mimicked NGF treatment. We found that NGF reduces Maxi-K channel opening by decreasing the activity of nifedipine-sensitive calcium channels. In conclusion, culture in NGF reduces the activity of L-type calcium channels, and secondarily, the calcium-sensitive activity of Maxi-K channels, rendering sympathetic neurons electrically hyper-responsive to bradykinin.

Key words: BK channel; M-current; Maxi-K channel; nifedipine-sensitive calcium channel; slo1 channel; superior cervical ganglion neurons

\section{Introduction}

Here we describe the effect of chronically culturing adult sympathetic neurons with nerve growth factor (NGF). NGF was discovered as a secreted protein essential for the survival of developing sympathetic and peripheral sensory neurons (Levi-Montalcini and Booker, 1960a, b). A few weeks after birth, neurons lose this dependence on NGF for survival (Orike et al., 2001; Hefti et al., 2006), but they still express receptors for NGF (Reinhardt et al., 1994), suggesting that NGF plays other roles in adult neurons. Interestingly, increased NGF levels have been detected in adult animal models for disease conditions, such as pancreatitis, chronic headache, and peripheral neuropathies (Toma et al., 2000; Sarchielli et al., 2001; Peleshok and Ribeiro-da-Silva, 2012),

Received April 15, 2014; revised July 24, 2014; accepted July 27, 2014.

Author contributions: 0.V., M.K., and B.H. designed research; 0.V. and M.K. performed research; 0.V., M.K., and B.H. analyzed data; O.V., M.K., and B.H. wrote the paper.

This work was supported by the National Institute of Neurological Disorders and Stroke, National Institutes of Health Grant R37NS008174, the Wayne E. Crill Endowed Professorship, and an Alexander von Humboldt-Foundation fellowship to M.K. We thank Drs. Andres Barria, Mark Bothwell, Peter B. Detwiler, Eamonn J. Dickson, Duk-Su Koh, Jong BaeSeo, and Jane M. Sullivan for reading the manuscript; A. Stratiievska and M. Munari for advice on culturing neurons; all members of the B.H. laboratory and colleagues in the Department of Physiology and Biophysics at the University of Washington for discussions and experimental advice; and Lea M. Miller for technical help.

The authors declare no competing financial interests.

*0.V. and M.K. contributed equally to this work.

Correspondence should be addressed to Dr. Bertil Hille, Department of Physiology and Biophysics, University of Washington School of Medicine, Box 357290, Seattle, WA 98195-7290. E-mail: hille@u.washington.edu.

DOI:10.1523/JNEUROSCI.1536-14.2014

Copyright $\odot 2014$ the authors $\quad 0270-6474 / 14 / 3411959-13 \$ 15.00 / 0$ which raises the question what role(s) NGF plays under such conditions.

One of the better understood effects of NGF in adulthood is sensitization of nociceptive neurons during inflammation, which leads to hyperalgesia. For example, thermal hyperalgesia can be mimicked by administration of a single dose of NGF (Lewin et al., 1994), and blocking the actions of NGF by injecting anti-NGF antibodies reduces hypersensitivity induced by inflammation (McMahon et al., 1995; Dmitrieva et al., 1997; Zahn et al., 2004; Ugolini et al., 2007). NGF-neutralizing antibodies are being assessed in clinical trials against chronic pain (Kumar and Mahal, 2012). On the cellular level, NGF regulates expression of several genes in nociceptive neurons and thereby increases the expression of proinflammatory molecules, such as substance $\mathrm{P}$ and calcitonin-gene related peptide (Lindsay and Harmar, 1989; Donnerer et al., 1992). In addition, NGF increases the excitability of nociceptive neurons by increasing the expression and trafficking of ion channels, such as TRPV1 (Zhang et al., 2005; Stein et al., 2006) and voltage-gated sodium channels (Friedel et al., 1997; Gould et al., 2000).

Adult sympathetic ganglion neurons also express NGF receptors and therefore can be affected by NGF during chronic inflammatory diseases (Peeker et al., 2000; Straub et al., 2006; Schnegelsberg et al., 2010; Longo et al., 2013). Here, we hypothesized that NGF sensitizes peripheral sympathetic neurons to proinflammatory molecules. One candidate is bradykinin (BK), a potent proinflammatory and hyperalgesic nonapeptide formed 
from plasma protein precursors after tissue injury. BK receptors are expressed in the sympathetic nervous system (Prado et al., 2002). BK can stimulate sympathetic neurons (Lewis and Reit, 1965 ) through activation of BK receptor Type 2 by closing $\mathrm{K}^{+}$permeable M-current channels (Jones et al., 1995). Here, we analyze how NGF alters the signaling pathway induced by BK in sympathetic neurons. We found a strong NGF-dependent sensitization of the electrical responses of sympathetic neurons to BK.

\section{Materials and Methods}

Culture of sympathetic neurons. Animals were handled according to guidelines approved by the University of Washington Institutional Animal Care and Use Committee. Neurons were isolated from superior cervical ganglia (SCG) of 7- to 12-week-old male Sprague Dawley rats by enzymatic digestion as described previously (Beech et al., 1991; Vivas et al., 2013). Isolated neurons were plated on poly-L-lysine (Sigma) coated glass chips and incubated in $5 \% \mathrm{CO}_{2}$ at $37^{\circ} \mathrm{C}$ in medium supplemented with $10 \%$ FBS. For many experiments, the cells were cultured in medium supplemented with either $1 \mathrm{ng} / \mathrm{ml}$ NGF (Invitrogen) or $2 \mu \mathrm{g} / \mathrm{ml}$ antiNGF antibody (Abcam, catalog \#ab6199, RRID:AB_2152414), but none of the recording solutions contained NGF or the anti-NGF antibody. For some experiments, the medium was supplemented with $200 \mathrm{~nm} \mathrm{K252a}$ (LC Laboratories) in addition to NGF. Recordings were performed on neurons with a membrane capacitance between 50 and $100 \mathrm{pF}$.

Photometric recordings. Optical measurements of calcium and Förster resonance energy transfer (FRET) were performed on single cells with a grating-controlled monochromatic light source (Polychrome IV; TILL Photonics) by whole-cell photometry (not with images) as previously described (Falkenburger et al., 2010; Dickson et al., 2013). For measurements of cytoplasmic free $\mathrm{Ca}^{2+}$, neurons were loaded for 40 min with 2 $\mu \mathrm{M}$ fura-2 AM (Invitrogen) dissolved in Ringer's solution containing $0.02 \%$ pluronic acid F-68, followed by a wash in Ringer's solution for 20 $\mathrm{min}$. FRET was measured as the ratio of corrected fluorescence from YFP and CFP after excitation of CFP molecules and is reported as the fluorescence emission ratio FRETr, defined as YFP/CFP.

Electrophysiology. Electrophysiological recordings were made with an EPC9 patch-clamp amplifier (HEKA) using $4 \mathrm{~m} \Omega$ patch pipettes. Membrane potentials were measured via current-clamp in the perforatedpatch configuration with $200 \mu \mathrm{M}$ amphotericin B (Sigma). The recording chamber was superfused at $2 \mathrm{ml} / \mathrm{min}$ with external solutions, permitting solution exchange with a time constant of $10 \mathrm{~s}$. The bath solution (Ringer's solution) contained $150 \mathrm{~mm} \mathrm{NaCl}, 2.5 \mathrm{~mm} \mathrm{KCl}, 2 \mathrm{~mm} \mathrm{CaCl}_{2}, 1 \mathrm{~mm}$ $\mathrm{MgCl}_{2}, 10 \mathrm{~mm} \mathrm{HEPES}$, and $8 \mathrm{~mm}$ glucose, adjusted with $\mathrm{NaOH}$ to $\mathrm{pH}$ 7.4. All agonists were applied for $20 \mathrm{~s}$. Agonists and blockers were dissolved in Ringer's solution to obtain a final concentration of $250 \mathrm{nM} \mathrm{BK}, 10 \mu \mathrm{M}$ oxotremorine methiodide (Oxo-M), 200 nm iberiotoxin (IbTX), $100 \mathrm{~nm}$ paxilline, $100 \mathrm{~nm}$ apamin, $200 \mathrm{nM}$ TTX, $100 \mu \mathrm{M} \mathrm{CdCl} \mathrm{Cl}_{2}$, or $5 \mu \mathrm{M}$ nifedipine. For a nominally $\mathrm{Ca}^{2+}$-free external solution, $\mathrm{CaCl}_{2}$ was replaced by $\mathrm{MgCl}_{2}$. The pipette solution contained $175 \mathrm{~mm} \mathrm{KCl}, 5 \mathrm{mM} \mathrm{MgCl}_{2}, 5 \mathrm{~mm}$ HEPES, $0.1 \mathrm{~mm} \mathrm{~K}_{4}$ BAPTA, $3 \mathrm{~mm} \mathrm{Na}_{2}$ ATP, and $0.1 \mathrm{~mm} \mathrm{Na}_{3} \mathrm{GTP}$, adjusted with $\mathrm{KOH}$ to $\mathrm{pH}$ 7.2. Sometimes the Maxi-K channels were activated by clamping free intracellular $\mathrm{Ca}^{2+}$ to $10 \mu \mathrm{M}$, using a pipette solution containing $95 \mathrm{~mm} \mathrm{KCl}, 20 \mathrm{~mm} \mathrm{~K}_{4}$ BAPTA, $19.8 \mathrm{mM} \mathrm{CaCl}_{2}, 1 \mathrm{~mm} \mathrm{MgCl}_{2}, 5 \mathrm{~mm}$ HEPES, $3 \mathrm{~mm} \mathrm{Na}_{2} \mathrm{ATP}$, and $0.1 \mathrm{~mm} \mathrm{Na}_{3} \mathrm{GTP}$, adjusted with $\mathrm{KOH}$ to $\mathrm{pH}$ 7.2. Potassium currents (M-current and $\mathrm{Ca}^{2+}$-activated $\mathrm{K}^{+}$currents) were recorded in whole-cell configuration with the described bath and pipette solutions. Series resistances of $6-10 \mathrm{~m} \Omega$ were compensated by $50 \%-70 \%$. Potassium currents were sampled at $2 \mathrm{kHz}$. M-current amplitude was measured from tail currents at $-60 \mathrm{mV}$ after a depolarizing voltage-step to $-20 \mathrm{mV}$ as the difference between the average current of the first $10-20 \mathrm{~ms}$ and the average current of the last $10 \mathrm{~ms}$. $\mathrm{Ca}^{2+}$ activated $\mathrm{K}^{+}$current was calculated by subtracting potassium currents recorded in the absence and presence of $\mathrm{CdCl}_{2}$ or IbTX.

Single-channel currents were recorded in the excised inside-out patchclamp configuration with symmetrical $\mathrm{K}^{+}$solutions, resulting in a potassium equilibrium potential of $0 \mathrm{mV}$. The bath solution mimicked the intracellular medium: $150 \mathrm{~mm} \mathrm{KCl}, 1 \mathrm{~mm} \mathrm{MgCl}_{2}, 2 \mathrm{~mm} \mathrm{CaCl}_{2}, 2 \mathrm{~mm}$ EGTA, 10 mm HEPES, adjusted with $\mathrm{KOH}$ to $\mathrm{pH}$ 7.3. The pipette solu- tion contained $150 \mathrm{~mm} \mathrm{KCl}, 2 \mathrm{~mm} \mathrm{CaCl}$, 2 mm $\mathrm{MgCl}_{2}, 200$ nм TTX, 10 mM HEPES, and was adjusted with $\mathrm{KOH}$ to $\mathrm{pH}$ 7.3. To calculate singlechannel conductances, current amplitude histograms were constructed from recordings at test potentials of $-80 \mathrm{mV}$ and $80 \mathrm{mV}$ and fitted with Gaussian curves to determine average current amplitudes for individual channel openings.

Transfection of sympathetic neurons. SCG neurons were transfected $18 \mathrm{~h}$ after isolation using an Eppendorf 5242 pressure microinjector and 5171 micromanipulator system (Eppendorf). cDNA was dissolved in 1 $\mathrm{mg} / \mathrm{ml}$ dextran-fluorescein solution $(10,000 \mathrm{kDa}$; Molecular Probes) to yield a final concentration of 50-150 $\mathrm{ng} / \mu \mathrm{l}$. cDNA was microinjected into the nucleus for $0.3 \mathrm{~s}$ at pressures of $80-120 \mathrm{hPa}$. Human eCFP-PH (phospholipase C $\delta 1$ [PLC $\delta 1]$ ) and eYFP-PH (PLC $\delta 1)$ plasmids were provided by K. Jalink (The Netherlands Cancer Institute, Amsterdam, Netherlands).

Data analysis. We used Igor Pro (Igor Software, RRID:nlx_156887) and Excel (Microsoft) to analyze data. Statistics are given as mean \pm SEM. Student's $t$ test was used to test for statistical significance. $p$ values $<0.05$ were considered significant.

\section{Results \\ NGF augments electrical responses of SCG neurons to BK stimulation}

In this work, we cultured rat SCG neurons with or without NGF for $48 \mathrm{~h}$. In both conditions, the neurons showed neurite outgrowth (Fig. 1A) and were able to fire action potentials upon stimulation. On average, there were more neurites with NGF. Culture with or without NGF did not affect the resting membrane potential (no NGF: $-57.4 \pm 0.9 \mathrm{mV}, n=19$; +NGF: $-55.8 \pm$ $1.0 \mathrm{mV}, n=20 ; p=0.25$ ) or resting cytoplasmic $\mathrm{Ca}^{2+}$ levels (fura-2 ratio in cell cultured without NGF: $0.093 \pm 0.002, n=18$; or with NGF: $0.096 \pm 0.004, n=17 ; p=0.55$ ).

BK directly excites sympathetic neurons of the rat and cat (Lewis and Reit, 1965; Jones et al., 1995). We asked whether incubation with NGF alters the electrical responses induced by BK. Rat SCG neurons cultured in the absence or presence of 1 $\mathrm{ng} / \mathrm{ml} \mathrm{NGF}$ for $48 \mathrm{~h}$ were studied with current-clamp recording in the perforated-patch configuration. In neurons cultured without NGF, application of $250 \mathrm{~nm}$ BK led to a small depolarization that evoked firing of action potentials in only $14 \%$ of cells $(n=$ 21 ; Figs. $1 B$ and $2 B, C$ ). In contrast, in neurons cultured for $48 \mathrm{~h}$ with NGF, BK elicited a significantly larger depolarization that evoked firing of action potentials in $80 \%$ of cells $(n=25$; Figs. $1 C$ and $2 B, C)$. The following experiments suggest that sensitization can be seen even when most voltage-gated sodium channels were blocked by $200 \mathrm{~nm}$ TTX to preclude action potential firing. With TTX in the recording solution, BK application to cells cultured without NGF led again to only a small depolarization $(3.5 \pm 0.6$ $\mathrm{mV}, n=5$; Fig. $1 D)$, whereas BK application to cells cultured in NGF led to significantly larger depolarization $(11.3 \pm 1.1 \mathrm{mV}$, $n=5, p=0.002$; Fig. $1 E)$.

\section{NGF augments $\mathrm{Ca}^{2+}$ signals evoked by $\mathrm{BK}$}

SCG neurons show $\mathrm{Ca}^{2+}$ elevations in response to BK application. We asked whether incubation with NGF also alters these signals. The first experiments used no recording pipette or voltage control, and the cells were loaded with fura-2 AM as a $\mathrm{Ca}^{2+}$ indicator. In control cells cultured for $48 \mathrm{~h}$ in the absence of NGF, BK evoked small $\mathrm{Ca}^{2+}$ elevations (Fig. $1 F, G$, black line), as reported previously (Cruzblanca et al., 1998; Zaika et al., 2007). However, following culture with $1 \mathrm{ng} / \mathrm{ml} \mathrm{NGF}$ for $48 \mathrm{~h}, \mathrm{BK}$ evoked fourfold larger and longer cytoplasmic $\mathrm{Ca}^{2+}$ signals (Fig. $1 F, G$, red line). Presumably, unlike the control neurons, NGFtreated ones fired action potentials as in Figure $1 C$. We found that 
A
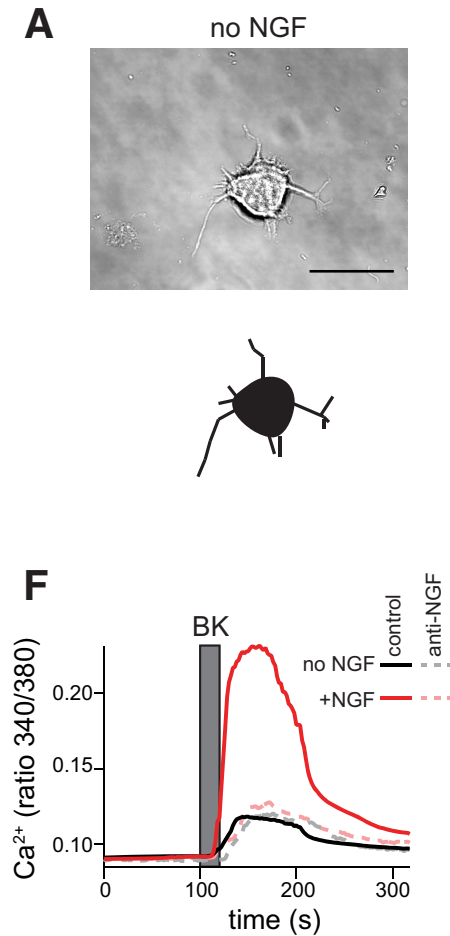
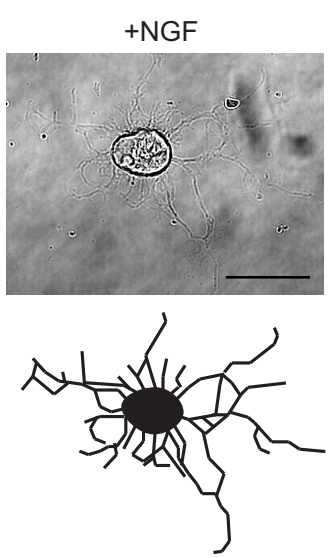

G

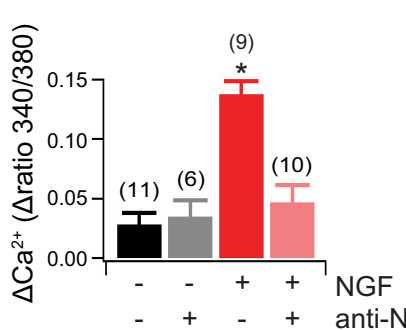

B
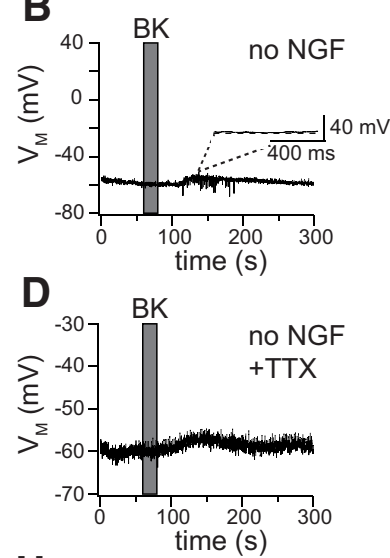

H

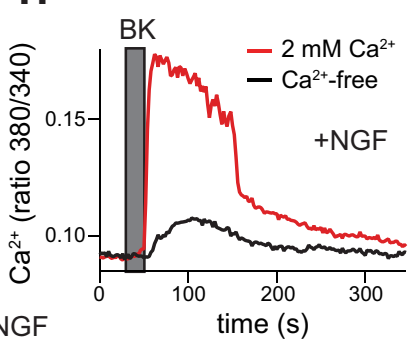

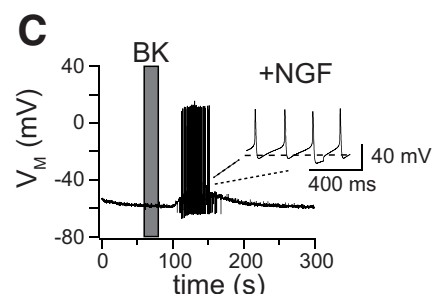

E

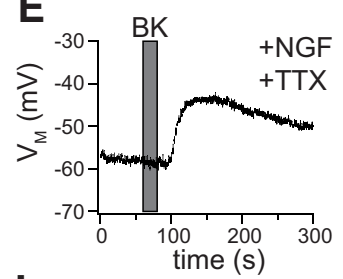

I

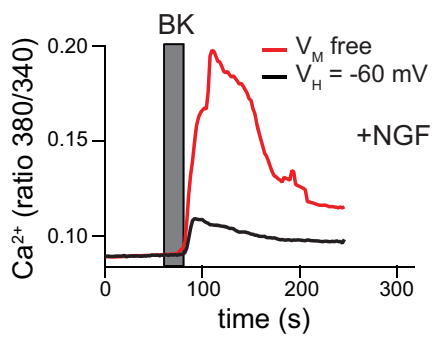

Figure 1. NGF increases BK-evoked electrical responses of SCG neurons and augments $\mathrm{Ca}^{2+}$ signals. $A$, Top, Phase-contrast images of SCG neurons cultured for $48 \mathrm{~h}$ with $2 \mu \mathrm{g} / \mathrm{ml}$ of an anti-NGF antibody (left) or with $1 \mathrm{ng} / \mathrm{ml} \mathrm{NGF} \mathrm{(right).} \mathrm{Scale} \mathrm{bar,} 20 \mu \mathrm{m}$. Bottom, Schematic drawings of the neurons shown in the top. $\boldsymbol{B}-\boldsymbol{E}$, Membrane potentials of SCG neurons were recorded in the perforated-patch configuration. Cells were cultured without or with $1 \mathrm{ng} / \mathrm{ml} \mathrm{NGF}$ as indicated, but NGF was removed immediately before the recordings. BK ( $250 \mathrm{~nm}$ ) was applied for $20 \mathrm{~s}$. Recordings were done in the presence or absence of $200 \mathrm{~nm}$ TTX where indicated. $F$, Cytoplasmic $\mathrm{Ca}^{2+}$ signals evoked by $250 \mathrm{~nm} \mathrm{BK}$ application in neurons cultured with or without NGF and $2 \mu \mathrm{g} / \mathrm{ml}$ anti-NGF antibody. Traces represent time courses of the fluorescence ratio of the $\mathrm{Ca}^{2+}$ indicator fura-2. $\boldsymbol{G}$, fura-2 ratio changes measured in experiments illustrated in $\boldsymbol{F}$. Numbers in parentheses indicate number of cells. No NGF vs + NGF, ${ }^{*} p<10^{-6} ;+$ NGF vs + NGF + anti-NGF, ${ }^{*} p=10^{-4}$. H, BK-evoked cytoplasmic $\mathrm{Ca}^{2+}$ signals in NGF-treated neurons in the presence and absence of external $\mathrm{Ca}^{2+} . I$, Cytoplasmic $\mathrm{Ca}^{2+}$ signals in NGF-cultured neurons clamped at a membrane potential of $-60 \mathrm{mV}$ or not manipulated ( $\mathrm{V}_{\mathrm{M}}$ free, no pipette).

A

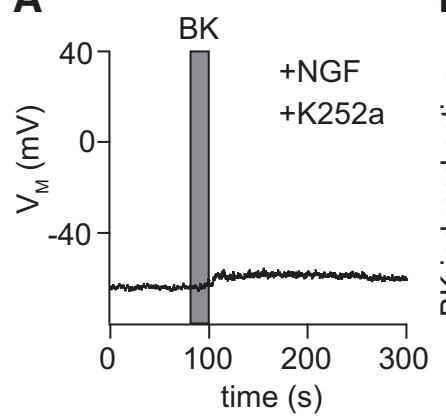

B

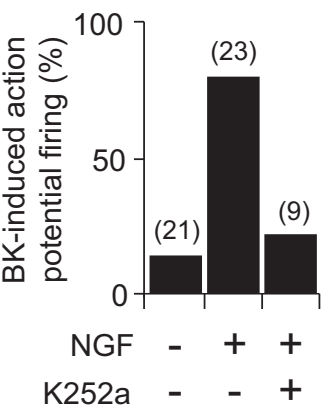

C

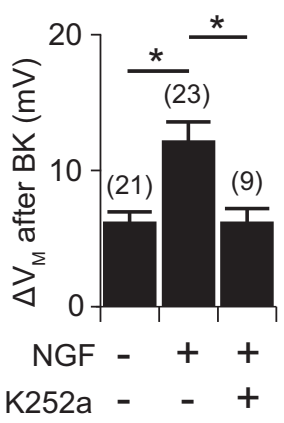

Figure 2. NGF-mediated sensitization to BK is dependent on trkA receptors. $A, S C G$ neurons were cultured with $1 \mathrm{ng} / \mathrm{mI}$ NGF and $200 \mathrm{~nm} \mathrm{K252a}$. Membrane potentials were measured in the perforated-patch configuration in the absence of TTX, and $250 \mathrm{~nm}$ BK was applied for 20 S. B , Percentage of SCG neurons firing action potentials after BK application after different culture conditions as indicated. C, Depolarization of membrane evoked by BKapplication in cells cultured as indicated: no NGF vs NGF, ${ }^{*} p=0.0004 ;$ NGF vs K252a, ${ }^{*} p=0.001$. Numbers in parentheses indicate number of cells.

a much higher NGF concentration $(50 \mathrm{ng} / \mathrm{ml})$, often used in published experiments (Delmas et al., 1998; Zaika et al., 2007), was no more effective than $1 \mathrm{ng} / \mathrm{ml}$ in these cells from 7 - to 12 -week-old rats. To exclude the possibility that the control cultures contained significant NGF either because of secretion or from the culture medium, we added an anti-NGF antibody to the medium with no added NGF. After $48 \mathrm{~h}$ in the antibody, cells responded to $\mathrm{BK}$ with the same small $\mathrm{Ca}^{2+}$ responses as without the antibody (Fig. $1 F$, G, dashed gray line). To confirm the ability of the antibody to neutralize NGF, we added NGF at the usual

concentration of $1 \mathrm{ng} / \mathrm{ml}$ to the antibodycontaining culture medium and tested $\mathrm{Ca}^{2+}$ signals after $48 \mathrm{~h}$. Under these conditions, the $\mathrm{Ca}^{2+}$ signals remained small and comparable with those from cells incubated without added NGF (Fig. $1 F, G$, dashed pink line). Thus, NGF incubation, even at modest concentrations, augments responses to $\mathrm{BK}$, and our culture medium contains little NGF, except when it is added exogenously.

The augmented $\mathrm{Ca}^{2+}$ signal evoked by BK in NGF-treated neurons depends on external $\mathrm{Ca}^{2+}$ and depolarization

To determine the source of the additional $\mathrm{Ca}^{2+}$ observed in NGF-treated neurons, we used a nominally $\mathrm{Ca}^{2+}$-free Ringer's solution before, during, and after BK application. NGF-treated SCG neurons superfused with $\mathrm{Ca}^{2+}$-free Ringer's solution showed reduced $\mathrm{Ca}^{2+}$ signals, comparable with those in cells cultured in the absence of NGF (Fig. $1 H$ ). Evidently, the augmented $\mathrm{Ca}^{2+}$ signals in NGFtreated SCG neurons depend on external $\mathrm{Ca}^{2+}$. We next asked whether a membrane depolarization underlies the extra $\mathrm{Ca}^{2+}$ influx. Therefore, in addition to loading the cells with fura-2 AM, we used perforated-patch electrical recording to control membrane potential changes. Under current clamp of NGF-treated cells, $\mathrm{Ca}^{2+}$ signals with BK were large (Fig. $1 I, \mathrm{~V}_{\mathrm{M}}$ free), whereas 
under voltage clamp at $-60 \mathrm{mV}, \mathrm{Ca}^{2+}$ signals were strongly reduced, becoming like those in neurons cultured in the absence of NGF (Fig. 1I). The need for external $\mathrm{Ca}^{2+}$ and for membrane depolarization suggests that culturing in NGF potentiates a BK-evoked influx of $\mathrm{Ca}^{2+}$ through voltage-gated calcium channels.

\section{Sensitization of SCG neurons to NGF depends on trkA receptors}

Two receptors for NGF have been found in SCG neurons: trkA and p75. trkA receptors bind NGF with high affinity $\left(\mathrm{K}_{\mathrm{d}}=\right.$ $10-100 \mathrm{pm})$, whereas p75 receptors bind NGF with low affinity $\left(K_{d}=100 \mathrm{pm}\right.$ to 2 nM) (Schechter and Bothwell, 1981; Hempstead et al., 1991; Bothwell, 1995; Ramer et al., 2001). Because $1 \mathrm{ng} / \mathrm{ml} \mathrm{NGF}$ $(\sim 40 \mathrm{pM})$ was enough to sensitize neurons to $\mathrm{BK}$, we tested for the involvement of trkA receptors in sensitization of the neurons. We cultured cells with NGF and an antagonist for trkA receptors, K252a, and measured the membrane potential responses to BK in perforated-patch currentclamp. Although $80 \%$ of neurons cultured with NGF alone fired action potentials upon stimulation with BK (Fig. $2 B$ ), only $22 \%$ of those cultured in NGF together with K252a fired (Fig. 2A,B). Similarly, the response rate was only $14 \%$ for neurons cultured in the presence of an anti-NGF antibody without added NGF (Fig. 2B). In addition, culturing neurons with K252a significantly reduced the membrane potential depolarization evoked by $\mathrm{BK}$ to the level observed in neurons cultured without NGF (Fig. $2 C ; p=0.001$ ). We conclude that high-affinity trkA receptors mediate the NGFinduced sensitization of SCG neurons to BK.

\section{Responses to muscarinic stimulation are not altered by NGF}

Neurotransmission between preganglionic fibers and postganglionic SCG neurons is mediated by acetylcholine. We focused on the muscarinic acetylcholine action. As with BK receptors, activation of muscarinic acetylcholine receptors depolarizes sympathetic neurons (Brown and Adams, 1980). We tested whether NGF can also augment electrical responses of SCG neurons to muscarinic stimulation. In neurons cultured either with or without NGF, application of $10 \mu \mathrm{M}$ of the general muscarinic agonist Oxo-M led to a strong depolarization and action potential firing (Fig. $3 A, B$ ). Even in TTX, muscarinic stimulation gave a large depolarization (with no action potentials) whether cells were cultured without NGF $(7.3 \pm 1.1 \mathrm{mV}, n=5$; Fig. $3 C)$ or with NGF $(8.9 \pm 1.0 \mathrm{mV}, n=5$; Fig. $3 D$, not significantly different from Oxo-M without NGF, $p=0.36$ ). The muscarinic cholinergic stimulation was not significantly different from BK stimulation in neurons cultured with NGF ( $p=0.2)$ but was significantly larger than with BK in neurons cultured without NGF $(p=0.03)$.

\section{Inhibition of M-current is not changed by NGF}

Because BK induces larger depolarization in neurons cultured in the presence of NGF, even without sodium channel activity, we investigated other ion channels. We looked for an altered inhibition of the KCNQ potassium channels that are responsible for the
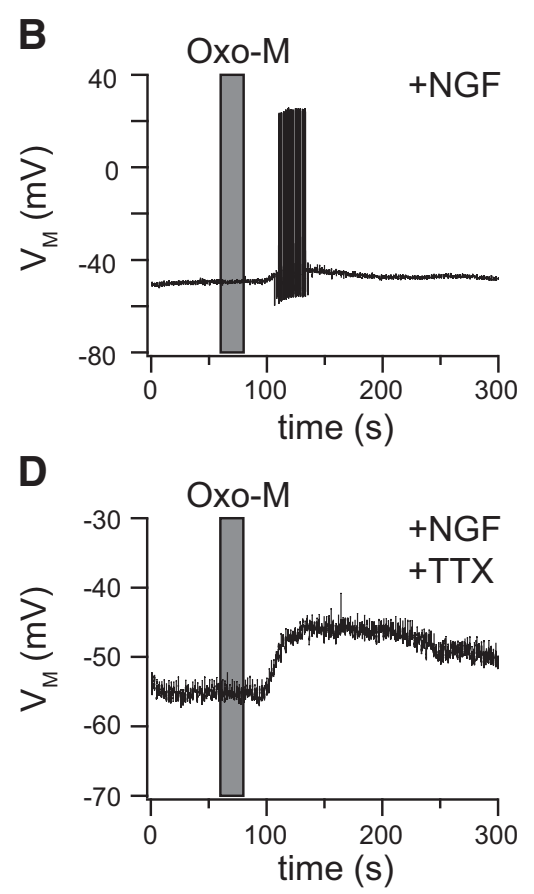
A

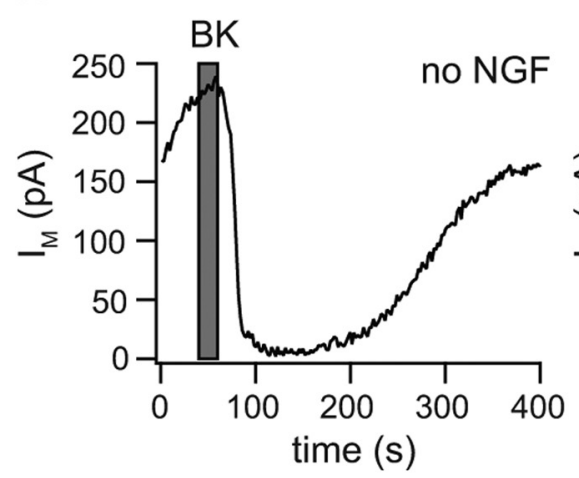

D

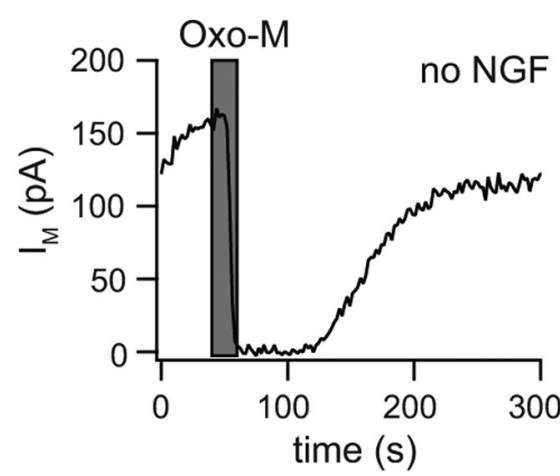

G

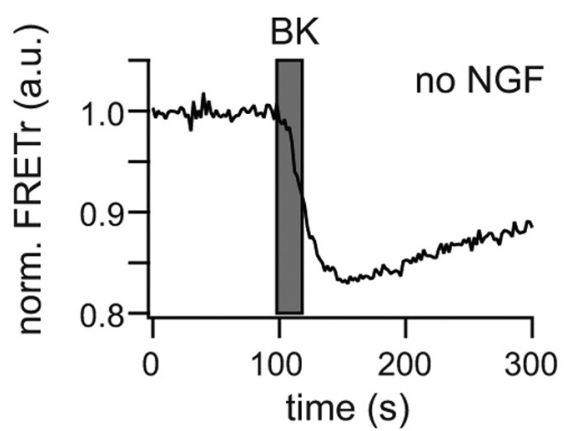

B

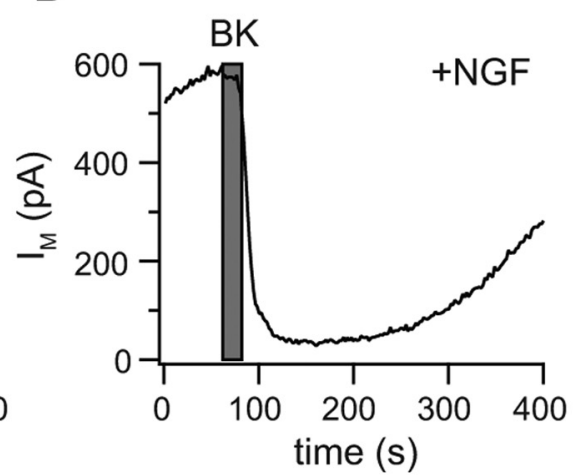

E

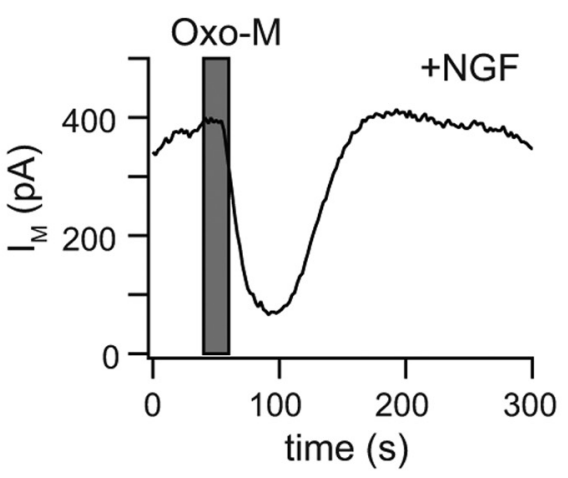

H

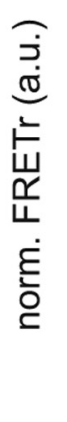

C

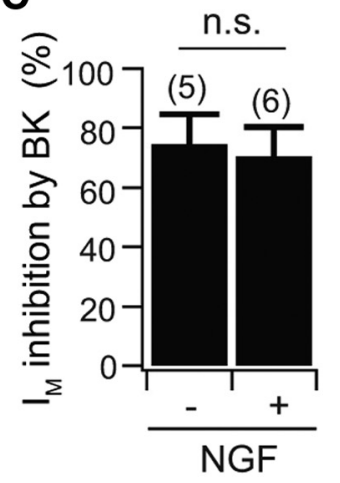

F

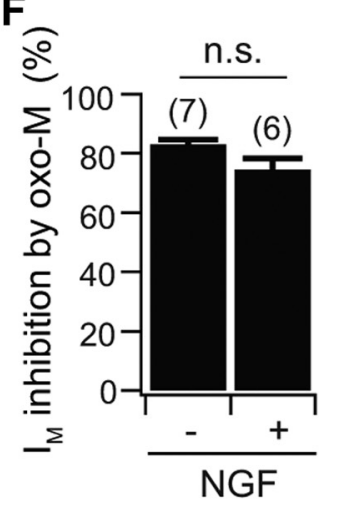

I

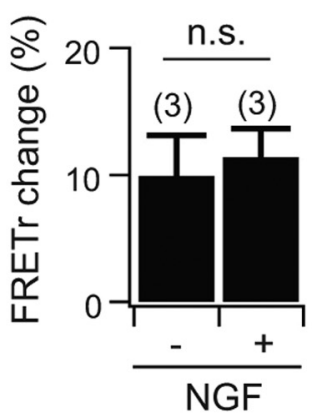

Figure 4. Inhibition of $\mathrm{M}$-current, $\mathrm{PI}(4,5) \mathrm{P}_{2}$ hydrolysis, and $\mathrm{IP}_{3}$ generation by BK receptor activation are independent of NGF-treatment. $\boldsymbol{A}, \boldsymbol{B}, \mathrm{Amplitude}$ of $\mathrm{M}$-current in response to 250 nM $B \mathrm{BK}$ application measured in whole-cell recordings in SCG neurons. Cells were cultured in the absence $(\boldsymbol{A})$ or presence of $1 \mathrm{ng} / \mathrm{mI} \mathrm{NGF}(\boldsymbol{B})$ for $48 \mathrm{~h}$ before experiments. $\boldsymbol{C}$, Percentage inhibition of $\mathrm{M}$-current by BK. D-F, Same experiment as in $\boldsymbol{A}-\boldsymbol{C}$, but with stimulation by $10 \mu \mathrm{m}$ 0x0-M instead of BK. G-I, SCG neurons were injected with plasmids for CFP-and YFP-tagged PH probes from PLC $\delta 1$. Neurons were stimulated with $B K$, and decreases in $F R E T$ ratio were measured to monitor loss of $\mathrm{PI}(4,5) \mathrm{P}_{2}$ and generation of $I P_{3}$. Before experiments, neurons were cultured in the absence $(\boldsymbol{G})$ or presence of $1 \mathrm{ng} / \mathrm{ml} \mathrm{NGF}(\boldsymbol{H})$ for $48 \mathrm{~h}$. I, Percentage change of FRETr between CFP- and YFP-tagged PH probes after application of BK. Numbers in parentheses indicate number of experiments.

normally colocalize at the plasma membrane at rest by binding to $\mathrm{PI}(4,5) \mathrm{P}_{2}$ headgroups and show FRET between CFP and YFP. Net depletion of membrane $\mathrm{PI}(4,5) \mathrm{P}_{2}$ and generation of cytoplasmic IP 3 lead to translocation of these probes to the cytoplasm and a reduction in their FRET interaction (Jensen et al., 2009; Falkenburger et al., 2010). Application of BK to SCG neurons led to reductions in FRET of PH domains that were not significantly different between nontreated or NGF-treated cells (Fig. 4G-I). Such experiments suggested that NGF does not alter the activity of $\mathrm{BK}$ receptors.

Maxi-K channels control electrical responses of SCG neurons Our measurements render unlikely models of the NGF effect that invoke changes of $\mathrm{I}_{\mathrm{M}}$ modulation or changes of receptor activity. Therefore, we looked at other ion channels that might be affected by culturing in NGF. Because BK induces a larger calcium signal in the presence of NGF, we tested the calcium-dependent Maxi-K channel (also named "BK channel," an abbreviation we avoid here, or KCa1.1, or $\mathrm{I}_{\mathrm{C}}$ ), which is present in SCG neurons (Adams et al., 1982a, b; Brown et al., 1982). This channel, activated by $\mathrm{Ca}^{2+}$ and depolarization, shows a very large single-channel conductance, so opening of only a few Maxi-K channels would suffice to hyperpolarize the membrane (Rothberg, 2012). We probed with IbTX to block Maxi-K channels selectively. These experiments were done on SCG neurons cultured without NGF while recording the membrane potential in current clamp with the perforated-patch configuration. As before, control experiments without IbTX showed no action potential firing during application of BK (Fig. 1B). In contrast, with the channel blocker present before and during the application of BK, there was action potential firing in $80 \%$ of neurons, mimicking the effect of culturing neurons for $48 \mathrm{~h}$ with NGF (Fig. $5 A$; for comparison, see 
A

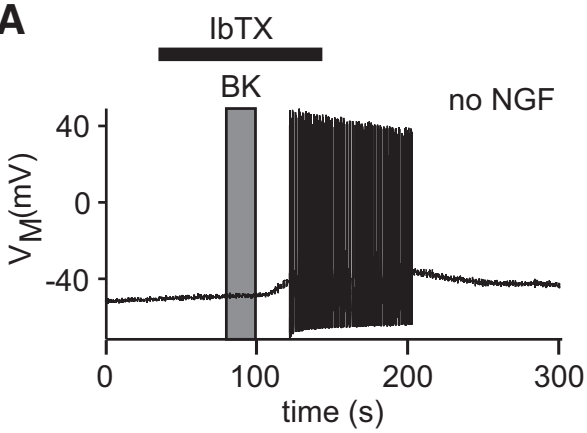

C

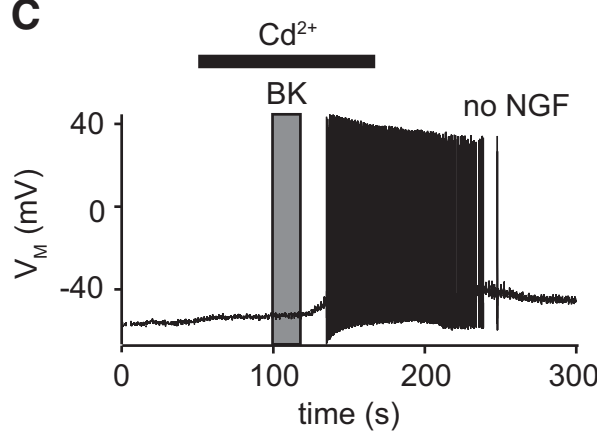

E

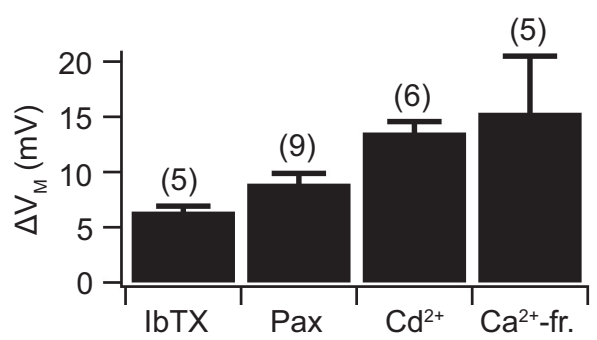

G

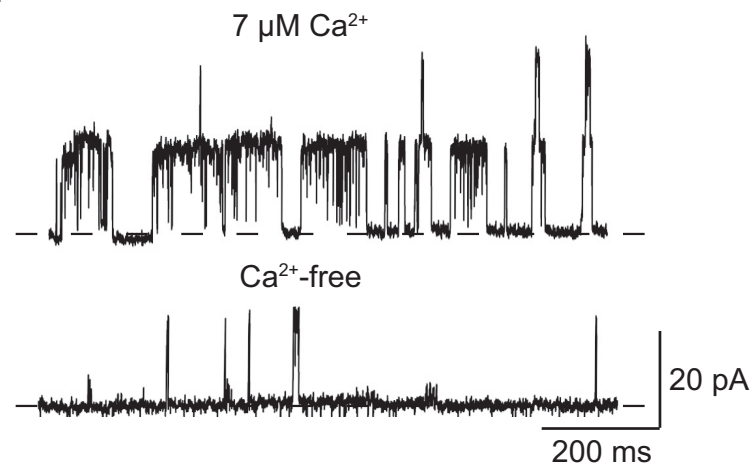

B

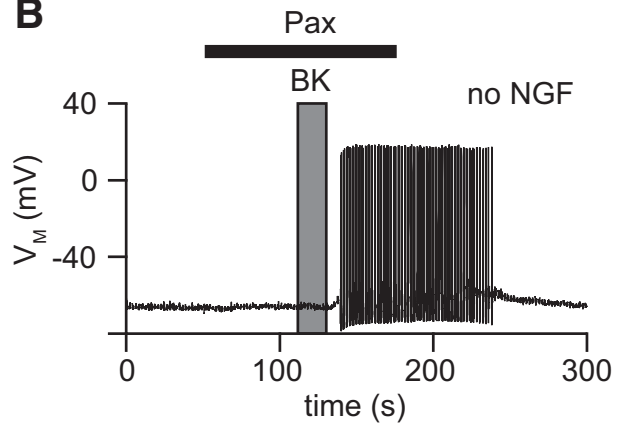

D

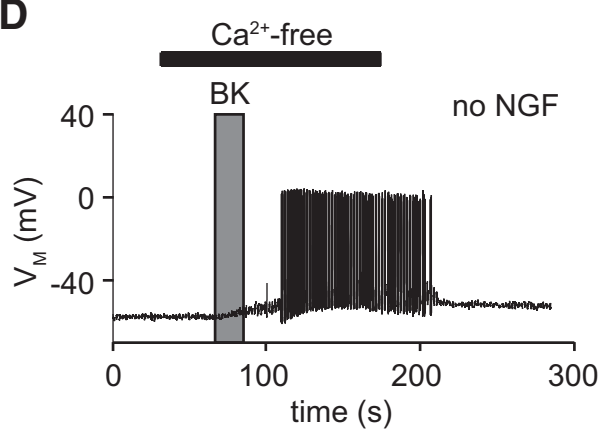

F

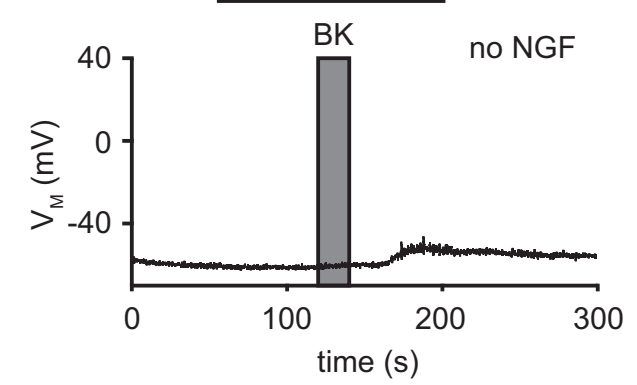

H

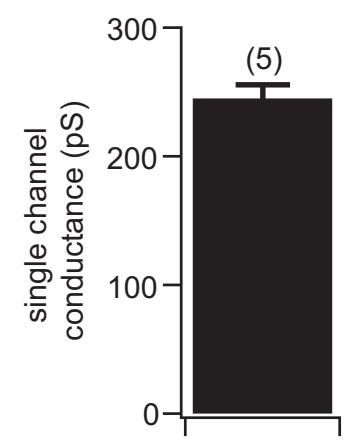

Figure 5. Maxi-K channel activity regulates electrical excitability of $S C G$ neurons. $A$, Neurons cultured for $48 \mathrm{~h}$ in the absence of $1 \mathrm{ng} / \mathrm{mI} \mathrm{NGF}$ were exposed to $200 \mathrm{~nm}$ IbTX before, during, and after $250 \mathrm{~nm}$ BK application. Membrane potentials were recorded in current clamp. $\boldsymbol{B}-\boldsymbol{D}$, Same experiment as in $\boldsymbol{A}$, but with superfusion of $100 \mathrm{~nm}$ paxilline $(\mathrm{Pax})(\boldsymbol{B}), \mathrm{Cd}^{2+}(\boldsymbol{C})$, or calcium-free $\left(\mathrm{Ca}^{2+}\right.$-free $)$ Ringer's solution $(\boldsymbol{D})$ as indicated by black bars. $\boldsymbol{E}$, Quantification of BK-evoked change in membrane potential measured in experiments displayed in $\boldsymbol{A}-\boldsymbol{D}$. $\boldsymbol{F}$, Same experiment as in $\boldsymbol{A}$, but with superfusion of $100 \mathrm{~nm}$ apamin. G, Single-channel recordings acquired in the inside-out patch-clamp configuration from membrane patches excised from SCG neurons cultured without NGF. Recordings were performed at a membrane potential of $80 \mathrm{mV}$ with either $7 \mu \mathrm{m}$ free $\mathrm{Ca}^{2+}$ in the bath or a nominally $\mathrm{Ca}^{2+}$-free solution. The channel closed level is indicated by a dashed line. $\boldsymbol{H}$, Calculated single-channel conductance from recordings as shown in $\mathbf{G}$. Numbers in parentheses indicate number of experiments.

Fig. 1C). Similar sensitization was observed with paxilline, a different inhibitor of Maxi-K channels (Fig. 5B). In the presence of paxilline, application of BK evoked action potentials in $67 \%$ of neurons. An alternative means to reduce the activation of Maxi-K channels is to reduce $\mathrm{Ca}^{2+}$ entry. We applied cadmium $\left(\mathrm{Cd}^{2+}\right)$ to block voltage-gated calcium channels before and during BK application or used $\mathrm{Ca}^{2+}$-free bathing solutions while applying BK. Under both experimental conditions, BK evoked action po- 
A
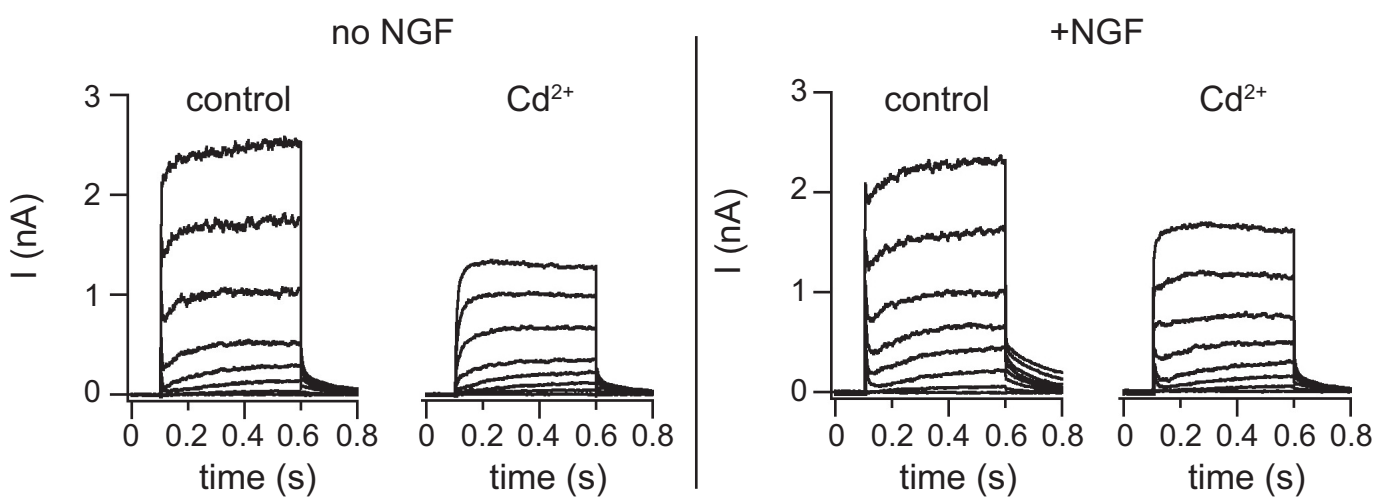

B

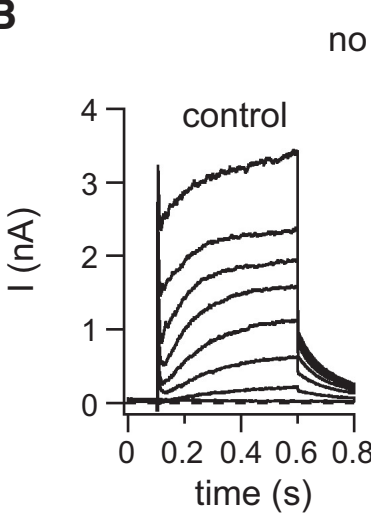

C

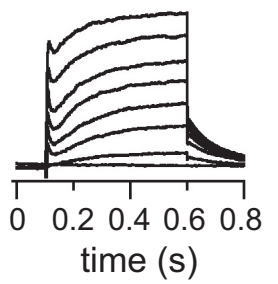

IbTX

D

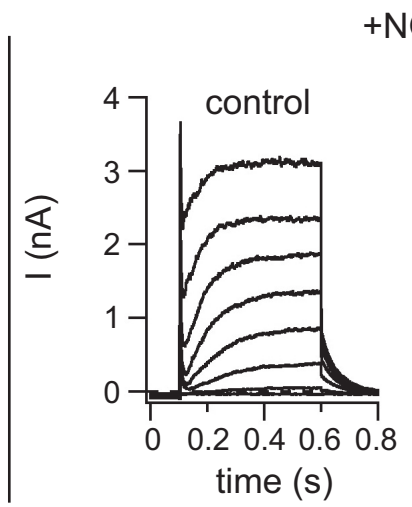

$+\mathrm{NGF}$

E
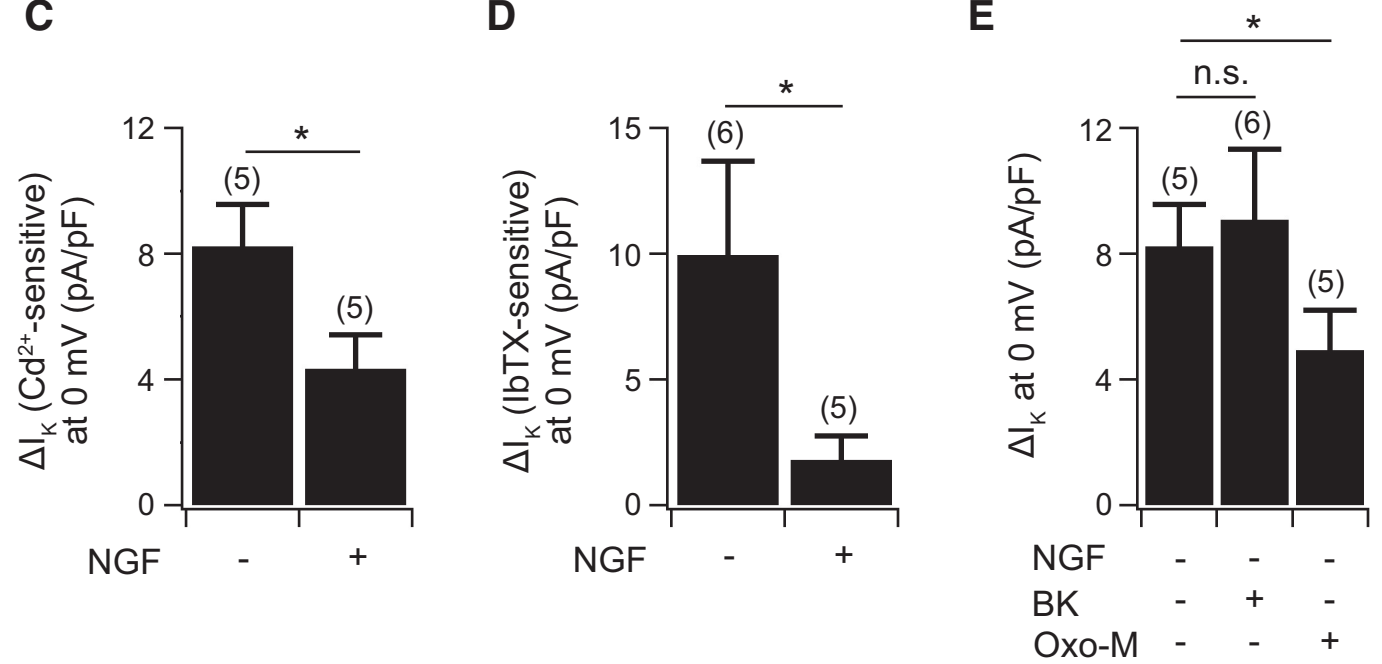

Figure 6. Maxi-K channel activity is regulated by NGF and muscarinic stimulation. $A$, Left, Traces of potassium outward currents recorded in whole-cell configuration from a neuron cultured without NGF before and after addition of $100 \mu \mathrm{m} \mathrm{Cd}{ }^{2+}$. Pulse protocol: Cells were depolarized in $10 \mathrm{mV}$ steps from a holding potential of $-50 \mathrm{mV}$ up to $20 \mathrm{mV}$ for $500 \mathrm{~ms}$ per voltage step. Right,

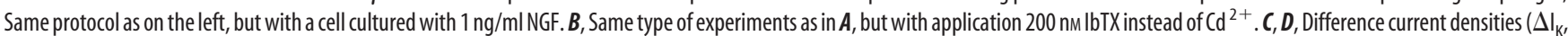
$\pm\left(\mathrm{Cd}^{2+}\right.$ or $\left.\pm \mathrm{IbTX}\right)$ at a membrane potential of $0 \mathrm{mV}$ calculated from recordings of neurons cultured without or with NGF as shown in $\boldsymbol{A}(p=0.04)$ or $(\boldsymbol{B})(p=0.05)$. $\boldsymbol{E}, \mathrm{SCG}$ neurons cultured in the absence of NGF were treated for $20 \mathrm{~s}$ with $250 \mathrm{~nm} B$ BK or $10 \mu \mathrm{m} 0 \mathrm{xo}$-M, respectively, whereas potassium outward currents were recorded as shown in $A$. Bars represent difference current densities at a membrane potential of $0 \mathrm{mV}$ under control conditions or after stimulation of cells with BK or $0 \mathrm{xo}-\mathrm{M}$ (control vs $0 \mathrm{xo}-\mathrm{Mp}=0.03$, n.s., Not significant, $p=0.78$ ). Numbers in parentheses indicate number of experiments.

tential firing in $80 \%$ of neurons despite culture without NGF (Fig. $5 C, D$ ). The observed changes in membrane potential are summarized in Figure 5E. In the presence of apamin, an inhibitor of small conductance calcium-activated potassium channels (SK channels), the application of BK induced only a small depolarization that was not enough to start a burst of action potentials (Fig. $5 F$ ), indicating that inhibition of Maxi-K channels, but not SK channels, mimics the NGF effect.
Using single-channel recording in excised inside-out membrane patches, we recorded activity attributable to Maxi-K channels in neurons cultured without NGF. Our recordings in symmetrical $\mathrm{K}^{+}$revealed large outward unitary currents at 80 $\mathrm{mV}$ that were dependent on intracellular $\mathrm{Ca}^{2+}$ concentration and corresponded to a single-channel conductance $(238 \pm 10 \mathrm{pS}$, $n=5$ patches) in the range reported for Maxi-K channels (Fig. $5 G, H)$ (Rothberg, 2012). Overall, these results confirm that 
Maxi-K channels actively participate in regulating electrical excitability of SCG neurons. Together with $\mathrm{I}_{\mathrm{M}}$, Maxi-K channels help to dampen electrical responses. Unlike $\mathrm{I}_{\mathrm{M}}$, Maxi-K channels are not active at resting membrane potential and cytoplasmic $\mathrm{Ca}^{2+}$ concentrations, so block with IbTX, or paxilline does not induce depolarization in resting cells (Fig. $5 A, B$, before application of BK).

\section{Maxi-K channel activity is sensitive to NGF treatment and needs $\mathrm{Ca}^{2+}$ influx} Our observations so far would be consistent with a reduction of Maxi-K channel activity in SCG neurons cultured with NGF. We tested this concept by voltage clamp. We first estimated Maxi-K channel-mediated current by subtracting total potassium outward currents during depolarizing steps before and after the application of $100 \mu \mathrm{M} \mathrm{Cd}{ }^{2+}$ (Fig. 6A). These measurements revealed a reduction by at least $50 \%$ of the calcium-sensitive outward current after $48 \mathrm{~h}$ culture with NGF (Fig. 6C). Repeating the experiment with $200 \mathrm{~nm}$ IbTX instead of $\mathrm{Cd}^{2+}$ gave the same result: culture in NGF had reduced the evoked Maxi-K current (Fig. $6 B, D)$. Such findings might explain why culturing SCG neurons with NGF makes them more responsive to $\mathrm{BK}$ but not why the neurons are easily excited by Oxo-M even when not cultured with NGF. We hy-

pothesized that Oxo-M alone depresses evoked Maxi-K channel activity. We recorded potassium outward currents before and after the application of $100 \mu \mathrm{M} \mathrm{Cd}^{2+}$ in the presence of Oxo-M or BK in neurons cultured in the absence of NGF and found indeed that Oxo-M, but not $\mathrm{BK}$, reduces depolarization-evoked $\mathrm{Cd}^{2+}$-sensitive outward currents (probably Maxi-K current) on its own (Fig. 6E).

In many cells, the $\mathrm{Ca}^{2+}$ entry that activates Maxi-K channels is mediated by L-type voltage-gated calcium channels (Rothberg, 2012; Rehak et al., 2013). We tested this possibility using the L-type $\mathrm{Ca}^{2+}$ channel blocker nifedipine. We performed current-clamp measurements in the perforated-patch configuration on SCG neurons cultured without NGF and applied nifedipine before and during application of BK. In the presence of nifedipine, BK initiated a strong depolarization, leading to action potential firing in $60 \%$ of neurons (Fig. $7 A, B$ ), whereas without nifedipine there was as before only a moderate depolarization and no action potential firing (Fig. $7 B$ ). Under voltage clamp, application of nifedipine led to a reduction of Maxi-K-mediated potassium current (Fig. $7 C$ ) similar to that observed with $\mathrm{Cd}^{2+}$ (Fig. 6A,C) or IbTX (Fig. $6 \mathrm{~B}, D)$. Although $>80 \%$ of the peak inward $\mathrm{Ca}^{2+}$ current in rat SCG neurons is carried by N-type $\mathrm{Ca}^{2+}$ channels (Plummer et al., 1989; Mathie et al., 1992), Maxi-K channel opening seems to depend on activation of the minority L-type $\mathrm{Ca}^{2+}$ channels. These two channel types must be near each other in the membrane. Apparently, even the small depolarization induced by BK in neurons cultured without NGF activates enough L-type $\mathrm{Ca}^{2+}$ channels to open Maxi-K channels.
B

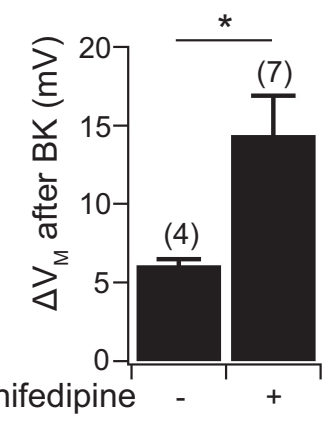

time (s) no NGF BK . (t) $80 \mathrm{mV}$ .... $400 \mathrm{~ms}$ control $+\mathrm{NGF}$ time (s)

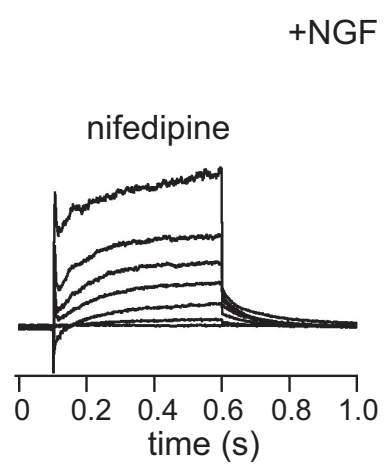

Figure 7. Inhibition of voltage-gated calcium channels by nifedipine sensitizes SCG neurons to BK. $A$, Current-clamp recording in the perforated-patch configuration of a neuron cultured without NGF. Nifedipine (5 $\mu \mathrm{m})$ and BK (250 nm) were applied as indicated. B, Quantification of BK-induced depolarization without or with nifedipine in neurons cultured without NGF. ${ }^{*} p<0.02$. Numbers in parentheses indicate number of experiments. $\boldsymbol{C}$, Left, Traces of potassium outward currents recorded from a neuron cultured with NGF. Right, Same cell recorded after addition of $5 \mu \mathrm{m}$ nifedipine. Voltage protocol: Cells were depolarized in $10 \mathrm{mV}$ steps from a holding potential of $-50 \mathrm{mV}$ up to $10 \mathrm{mV}$ for $500 \mathrm{~ms}$ per voltage step.

NGF reduces activation of Maxi-K channels by reducing Ltype calcium channel activity

Our findings led us to ask whether culture in NGF decreases the density of Maxi-K channels in the plasma membrane or decreases their activation. We assessed Maxi-K channel density by recording potassium currents in voltage clamp with elevated $\mathrm{Ca}^{2+}$ in the pipette and nifedipine in the bath. The pipette solution contained $20 \mathrm{~mm}$ BAPTA and sufficient $\mathrm{CaCl}_{2}$ to raise cytoplasmic free $\mathrm{Ca}^{2+}$ to $\sim 10 \mu \mathrm{M} \mathrm{Ca}{ }^{2+}$. Under these recording conditions, Maxi- $\mathrm{K}$ channels are activated by the free $\mathrm{Ca}^{2+}$ in the pipette solution, rather than by L-type $\mathrm{Ca}^{2+}$ channels. We elicited potassium outward currents by depolarizing voltage steps from a holding potential of $-50 \mathrm{mV}$ (Fig. $8 A$ ). The IbTX-sensitive potassium currents showed indistinguishable current densities in cells cultured with or without NGF (Fig. $8 B$ ). Hence, incubation with NGF may not reduce the density of Maxi-K channels at the cell surface but may instead reduce their activation.

We next hypothesized that NGF reduces Maxi-K channel currents by reducing $\mathrm{Ca}^{2+}$ entry via L-type calcium channels. We compared the nifedipine-sensitive calcium currents of neurons cultured without or with NGF (Fig. 8C). As predicted, nifedipine inhibited more current in neurons cultured without NGF (16 \pm $3 \%, n=7)$ than in those cultured with NGF $(6 \pm 3 \%, n=5, p=$ 0.035; Fig. $8 D$ ), whereas total calcium channel-mediated current density was unaltered (no NGF: $-31.0 \pm 2.3 \mathrm{pA} / \mathrm{pF}$, +NGF: $-26.8 \pm 2.2 \mathrm{pA} / \mathrm{pF}, n=25, p=0.20)$. Thus, NGF treatment reduces L-type calcium current that governs the activity of Maxi-K channels. 
A
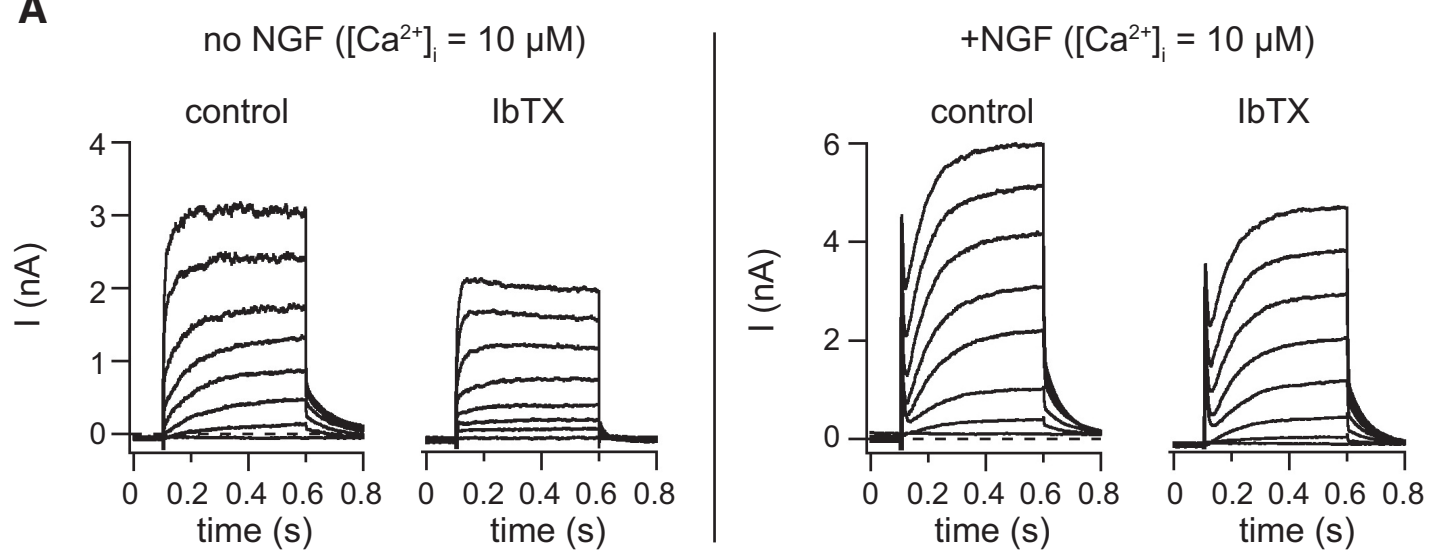

B

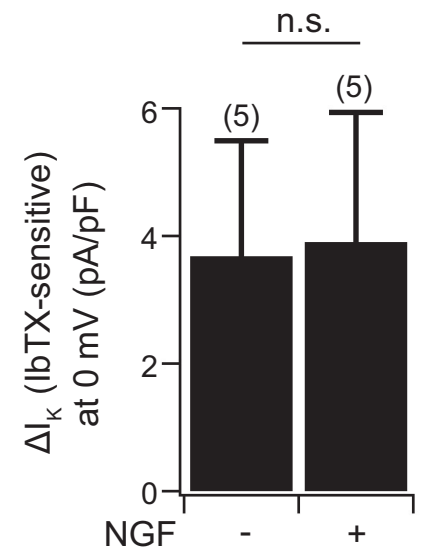

C

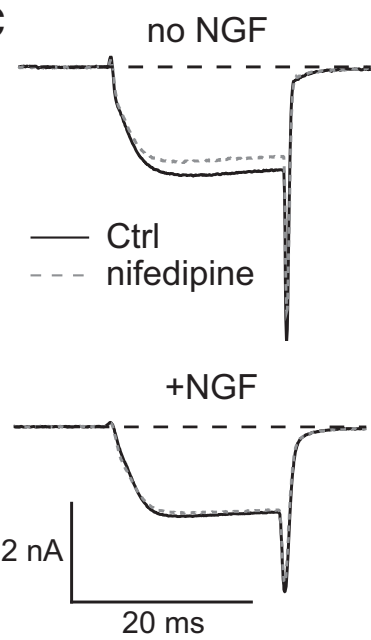

D

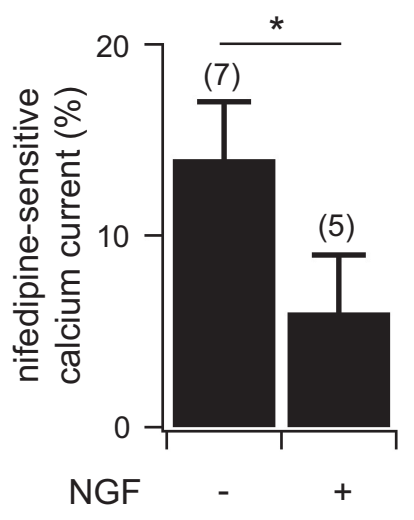

Figure 8. NGF reduces the activating $\mathrm{Ca}^{2+}$ entry rather than Maxi-K channel density. $\boldsymbol{A}$, Left, Potassium currents recorded from a neuron cultured without NGF before and after addition of 200 nм IbTX. The pipette solution contained a calcium-BAPTA mixture that buffered cytoplasmic free $\mathrm{Ca}^{2+}$ to $10 \mu m \mathrm{Ca}^{2+}$. The bath solution contained $10 \mu \mathrm{m}$ nifedipine to inhibit L-type $\mathrm{Ca}^{2+}$ channel

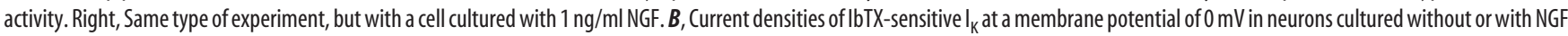
as shown in A. n.S., Not significant; $p=0.94$. C, Traces of total calcium inward currents during a step to $0 \mathrm{mV}$ from a holding potential of $-80 \mathrm{mV}$ from neurons cultured without (top) or with NGF (bottom), before and after application of $5 \mu \mathrm{m}$ nifedipine. Pulse protocol:P/4.D, Percentage of nifedipine-sensitive calcium current in recordings as shown in $C$. ${ }^{*} p=0.035$. Numbers in parentheses indicate number of experiments.

\section{Some properties of acutely isolated SCG neurons are like those of cells cultured in the absence of NGF}

The obvious effect of NGF on neuronal responses made us wonder whether the native state of these cells was more like the cultures that had NGF or the cultures that lacked it. As a first approach, we compared electrical responses of the $48 \mathrm{~h}$ cultured neurons to those of acutely dissociated neurons. We isolated neurons $(\sim 2 \mathrm{~h})$ and allowed them to adhere to poly-L-lysine-covered glass chips for only $30 \mathrm{~min}$. Soon afterward, the cells were analyzed by current-clamp recordings in the perforated-patch configuration, and BK was applied. Like cells cultured without NGF, only $11 \%$ of these uncultured, acutely dissociated neurons fire action potentials upon BK application and showed only a small depolarization of the membrane potential (Fig. 9A,C).

Might these acutely dissociated neurons be temporarily damaged by the enzymes and mechanical trauma of the isolation procedure? As one control, we cultured cells for $48 \mathrm{~h}$ in NGF, so they reached a sensitized state and then treated them with enzymes again to mimic the acute isolation procedure. The cultured cells were incubated for $20 \mathrm{~min}$ with collagenase and dispase at $37^{\circ} \mathrm{C}$. Perforated-patch current-clamp recordings then revealed action potential firing and significant depolarization of the mem- brane potential after BK application (Fig. 9B,C). Therefore, we conclude that incubation with these enzymes does not reverse NGF sensitization of BK responses.

To understand better how SCG neurons are sensitized by NGF, we determined the induction time of the NGF action. The experiment began with neurons in an NGF-free initial condition. After culture for $48 \mathrm{~h}$ with an anti-NGF antibody, we changed the culture medium to one containing $1 \mathrm{ng} / \mathrm{ml}$ NGF and no antibody. Using the perforated-patch configuration, we recorded membrane potential responses periodically starting $1 \mathrm{~h}$ after the switch to NGF. Depolarizations evoked by BK began to increase after $6 \mathrm{~h}$ and grew gradually over $48 \mathrm{~h}$ (Fig. 9D). The percentage of neurons firing action potentials after BK application increased in parallel, starting at only $17 \%$ after $1 \mathrm{~h}$ in NGF and reaching $72 \%$ after $24 \mathrm{~h}$ (Figs. $9 E$ and $2 B$ ). To study the time course of reversal of these effects, neurons were cultured for $48 \mathrm{~h}$ with $1 \mathrm{ng} / \mathrm{ml} \mathrm{NGF}$ and then rinsed with medium lacking NGF and cultured with an anti-NGF antibody. Interestingly, the membrane potential depolarizations after BK remained high for $24 \mathrm{~h}$ without NGF and were only partially decreased at $48 \mathrm{~h}$ (Fig. 9D). Similarly, the reduction in the percentage of cells firing action potentials after BK application was slow (Fig. 9E). Even $48 \mathrm{~h}$ after NGF removal, 
A

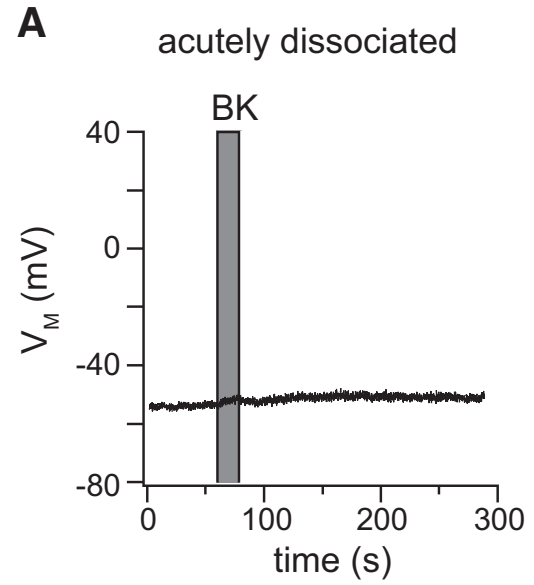

B

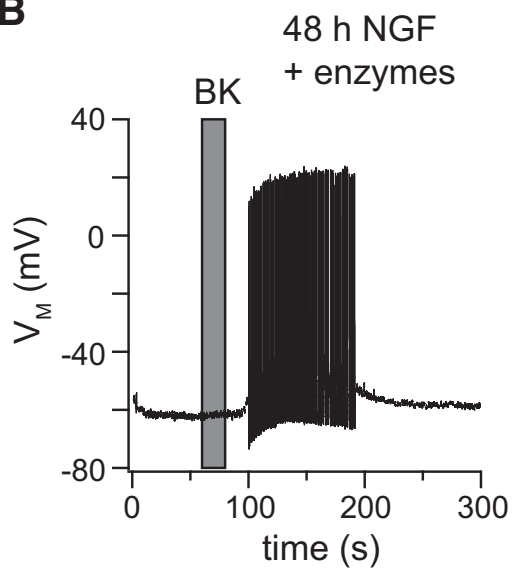

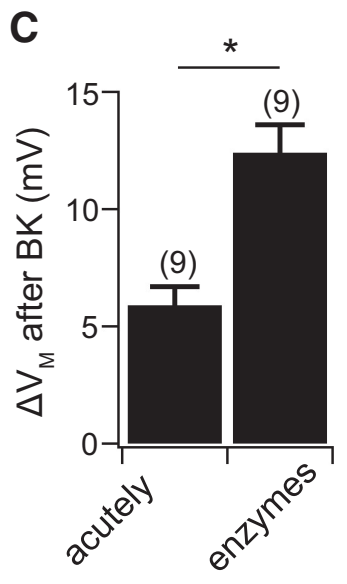

D

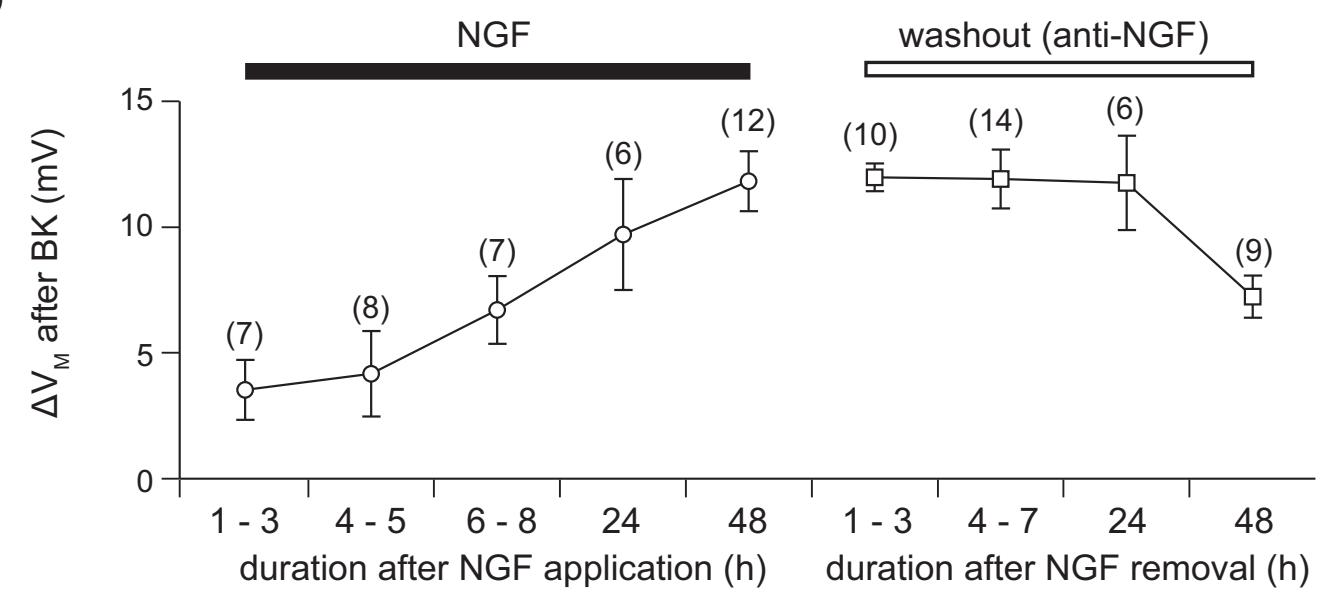

E

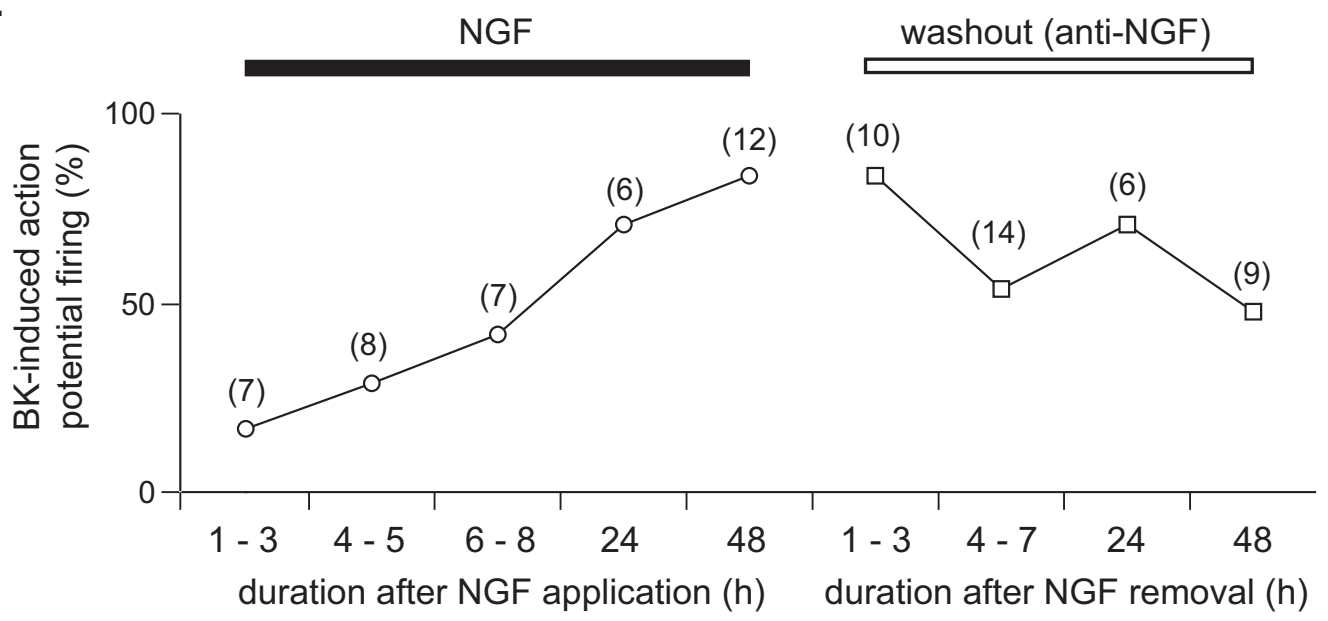

Figure 9. Acutely dissociated SCG neurons show electrical excitability similar to cells cultured without NGF. $A$, Current-clamp recording in the perforated-patch configuration of a neuron acutely isolated from SCG. BK (250 nM) was applied as indicated. B, Same type of recording as in $A$, but from a neuron cultured for $48 \mathrm{~h}$ with $1 \mathrm{ng} / \mathrm{ml}$ NGF and then treated with collagenase and dispase for $20 \mathrm{~min}$ before the recording. C, Quantification of changes in membrane potential after BK application from cells either acutely dissociated or cultured for $48 \mathrm{~h}$ with NGF and followed by collagenase and dispase for 20 min ("enzymes"). ${ }^{*} p<0.001$. D, Left, Mean membrane potential depolarizations evoked by a $20 \mathrm{~s}$ BK application measured in perforated-patch recordings from SCG neurons cultured for the indicated amount of time with $1 \mathrm{ng} / \mathrm{ml} \mathrm{NGF} \mathrm{(closed} \mathrm{bar)} \mathrm{after} \mathrm{prior} 48 \mathrm{~h}$ culture without NGF. Right, Same type of experiment, but neurons were cultured for $48 \mathrm{~h}$ with $1 \mathrm{ng} / \mathrm{ml}$ NGF and subsequently cultured in medium with an anti-NGF antibody (open bar) for the indicated amount of time. $\boldsymbol{E}$, Percentage of cells firing action potentials after BK application in the same experiment as in $\boldsymbol{D}$. Numbers in parentheses indicate number of cells.

we still observed action potential firing in $44 \%$ of neurons compared with $14 \%$ in control neurons (Fig. $2 B$ ). Thus, it takes hours after first exposure to NGF before SCG neurons show measurable increases in excitability and several days for recovery. Consider- ing that to record from acutely isolated neurons it took $<2 \mathrm{~h}$ after killing the animal, and that the NGF effect reverses only partially after $48 \mathrm{~h}$, we concluded that our results with acutely dissociated neurons are not due to NGF loss during the dissection protocol. 
In summary, acutely isolated neurons behave like cells cultured without NGF and because the reversibility of NGF effect takes days, we suggest that these resemble the native state of SCG neurons.

\section{Discussion}

We tested the effects of NGF on adult sympathetic neurons and found that culturing in NGF sensitizes adult sympathetic neurons to BK. Only after treatment with NGF does BK cause sympathetic neurons to depolarize enough to fire action potentials. NGF treatment does not alter the ability of BK to activate PLC and inhibit M current. Instead, it reduces L-type calcium channel activity, thereby decreasing the depolarization-evoked activation of Maxi-K channels and increasing electrical excitability of these neurons.

First, we discuss NGF-mediated sensitization observed in other types of adult neurons. For example, NGF sensitizes responses of adult, but not neonatal, nociceptive neurons to noxious stimuli in minutes (Shu and Mendell, 1999; Bonnington and McNaughton, 2003; Zhu et al., 2004; Zhang et al., 2005). NGF also renders capsaicin-sensitive small sensory neurons more responsive to BK (Kasai et al., 1998; Kasai and Mizumura, 1999). On a longer time scale, exposure of cells to NGF for $4-48 \mathrm{~h}$ also sensitizes bladder afferent neurons (Yoshimura et al., 2006) and brainstem neurons (Bie et al., 2010), and exposure to NGF for several days sensitizes skin nociceptors yielding heightened responses to touch and induction of behaviors that protect the affected area (Hefti et al., 2006; Pezet and McMahon, 2006; Rukwied et al., 2013). Sensitization of bladder afferents correlates with overreactivity of the bladder (Yoshimura et al., 2006), and sensitization of brainstem neurons to opioids promotes mechanisms predisposing for drug addiction (Bie et al., 2012). We find that NGF sensitizes sympathetic neurons to the proinflammatory molecule BK.

NGF levels change during pathological conditions. Basal NGF levels in serum are normally low $(2-40 \mathrm{pg} / \mathrm{ml}$ ) (Toma et al., 2000; Sarchielli et al., 2001; Peleshok and Ribeiro-da-Silva, 2012; Diniz et al., 2013; Palumbo et al., 2013; Peng et al., 2013) and increase threefold to fivefold during urinary or abdominal inflammation (Lewin et al., 1994; Dmitrieva et al., 1997; Sarchielli et al., 2001; Jiang et al., 2013; Liu et al., 2013), diseases with involvement of the sympathetic nervous system (Hohenfellner et al., 1992; Peeker et al., 2000; Buffington, 2004; Lutgendorf et al., 2004; Straub et al., 2006; Schnegelsberg et al., 2010). In agreement with low resting levels of NGF in vivo, we found that acutely dissociated sympathetic neurons were not depolarized much by BK, whereas culture for $>6 \mathrm{~h}$ in NGF was enough to sensitize them to BK. Further experiments comparing in vivo NGF effects in control and in inflamed models would help to establish a physiological significance for our findings.

Much literature about electrical excitability and $\mathrm{Ca}^{2+}$ signals of isolated SCG neurons concerns cells from neonatal to 2-weekold rats. The survival of these young cells still depends on NGF. Commonly, 25-100 ng/ml NGF is added to supplement the culture medium of neonatal neurons (Lindsay and Harmar, 1989; Donnerer et al., 1992; Cruzblanca et al., 1998; Brown et al., 2007; Zaika et al., 2007; Brown and Passmore, 2009). In our study, we cultured neurons from older rats that apparently no longer require NGF to survive (Orike et al., 2001; Ramer et al., 2001; Hefti et al., 2006). They survived for several days in the absence of NGF with no apparent morphological or functional signs of stress. Indeed, even culturing the cells in the presence of an NGFneutralizing anti-NGF antibody did not alter cell survival rates, cell morphology, action potential firing patterns, or potassium channel activity. Thus, we do not need to invoke extraneous sources of NGF in our cultures to explain cell survival and activity, and we confirm that sympathetic neurons from adult rats lose their dependence on NGF for survival and cellular activity. Nonetheless, culture in a low concentration of NGF still sensitizes adult SCG neurons to proinflammatory molecules, such as BK, and it promotes greater outgrowth of neurites.

We found that NGF reduces L-type calcium current and hence the evoked activity of Maxi-K channels. Other sensitization mechanisms have been proposed for sensory and brainstem neurons. Acute application of NGF to sensory neurons increases surface expression of channels like TRPV1, sensors of noxious levels of heat, lowering the threshold for pain (Zhang et al., 2005; Stein et al., 2006), whereas long-term application of NGF to brainstem neurons increases the surface expression of $\delta$-opioid receptors (Bie et al., 2010). We did not find evidence for an alteration in BK receptor Type 2 activity by NGF, as indicated by similar amounts of $\mathrm{M}$ current inhibition and $\mathrm{PI}(4,5) \mathrm{P}_{2}$ hydrolysis. The ability of NGF to regulate ion channels has been documented in numerous reports. For instance, NGF increases both TTX-resistant and TTX-sensitive sodium channel activities in PC12 cells, sensory neurons, and bullfrog sympathetic ganglion neurons on a rapid time scale of a few minutes up to $24 \mathrm{~h}$ (Garber et al., 1989; Friedel et al., 1997; Lei et al., 1997; Gould et al., 2000; Zhang et al., 2002). NGF also increases or decreases voltage-gated potassium currents on a similar time scale (Sharma et al., 1993; Luther and Birren, 2006, 2009; Bai et al., 2010). After 2 d in NGF, we found a significant reduction in L-type calcium channel currents in adult SCG neurons, secondarily reducing evoked currents in Maxi-K channels. In preliminary experiments not shown, we also tested for an NGF effect on Maxi-K current on small sensory neurons, but we did not find evidence for one. Other studies find increases in L-type calcium channel currents in adult bullfrog sympathetic ganglion B neurons (Ford et al., 2008), somatotrope-like GH3 cells (López-Domínguez et al., 2006), and pancreatic $\beta$-cells (Rosenbaum et al., 2002). Future experiments need to be done to explain why the L-type channels of SCG neurons respond to NGF differently and to identify the underlying molecular mechanisms.

In conclusion, our working model postulates that BK application first inhibits M-current. This leads to an initial small depolarization of the membrane potential that activates L-type calcium channels and subsequently Maxi-K channels. Activation of Maxi-K channels counterbalances the closure of $\mathrm{M}$ channels, restricts any membrane depolarization, and prevents action potential firing. After culture in NGF, the calcium influx through L-type calcium channels is reduced, with fewer Maxi-K channels open; therefore, BK depolarizes neurons enough to evoke action potential firing. Finally, as a consequence of action potential firing, calcium enters into the cell through $\mathrm{N}$-type calcium channels and causes a large transient increase in cytoplasmic calcium. This NGF-mediated sensitization is observed for stimulation by BK but not by Oxo-M. Insensitivity of muscarinic acetylcholine signaling to NGF is probably explained by the ability of muscarinic receptors to inhibit L-type calcium channels in these neurons preventing activation of Maxi-K channels (Mathie et al., 1992; Zaika et al., 2007).

\section{References}

Adams PR, Brown DA, Constanti A (1982a) M-currents and other potassium currents in bullfrog sympathetic neurones. J Physiol 330:537-572. Medline

Adams PR, Constanti A, Brown DA, Clark RB (1982b) Intracellular $\mathrm{Ca}^{2+}$ 
activates a fast voltage-sensitive $\mathrm{K}^{+}$current in vertebrate sympathetic neurones. Nature 296:746-749. CrossRef Medline

Bai Y, Dergham P, Nedev H, Xu J, Galan A, Rivera JC, ZhiHua S, Mehta HM, Woo SB, Sarunic MV, Neet KE, Saragovi HU (2010) Chronic and acute models of retinal neurodegeneration TrkA activity are neuroprotective whereas p75NTR activity is neurotoxic through a paracrine mechanism. J Biol Chem 285:39392-39400. CrossRef Medline

Beech DJ, Bernheim L, Mathie A, Hille B (1991) Intracellular $\mathrm{Ca}^{2+}$ buffers disrupt muscarinic suppression of $\mathrm{Ca}^{2+}$ current and $\mathrm{M}$ current in rat sympathetic neurons. Proc Natl Acad Sci U S A 88:652-656. CrossRef Medline

Bie B, Zhang Z, Cai YQ, Zhu W, Zhang Y, Dai J, Lowenstein CJ, Weinman EJ, Pan ZZ (2010) Nerve growth factor-regulated emergence of functional $\delta$-opioid receptors. J Neurosci 30:5617-5628. CrossRef Medline

Bie B, Wang Y, Cai YQ, Zhang Z, Hou YY, Pan ZZ (2012) Upregulation of nerve growth factor in central amygdala increases sensitivity to opioid reward. Neuropsychopharmacology 37:2780-2788. CrossRef Medline

Bonnington JK, McNaughton PA (2003) Signalling pathways involved in the sensitisation of mouse nociceptive neurones by nerve growth factor. J Physiol 551:433-446. CrossRef Medline

Bothwell M (1995) Functional interactions of neurotrophins and neurotrophin receptors. Annu Rev Neurosci 18:223-253. CrossRef Medline

Brown DA, Adams PR (1980) Muscarinic suppression of a novel voltagesensitive $\mathrm{K}^{+}$current in a vertebrate neurone. Nature 283:673-676. CrossRef Medline

Brown DA, Passmore GM (2009) Neural KCNQ $\left(K_{V} 7\right)$ channels. Br J Pharmacol 156:1185-1195. CrossRef Medline

Brown DA, Adams PR, Constanti A (1982) Voltage-sensitive K-currents in sympathetic neurons and their modulation by neurotransmitters. J Auton Nerv Syst 6:23-35. CrossRef Medline

Brown DA, Hughes SA, Marsh SJ, Tinker A (2007) Regulation of $M\left(K_{V} 7.2 /\right.$ 7.3) channels in neurons by $\mathrm{PIP}_{2}$ and products of $\mathrm{PIP}_{2}$ hydrolysis: significance for receptor-mediated inhibition. J Physiol 582:917-925. CrossRef Medline

Buffington CA (2004) Comorbidity of interstitial cystitis with other unexplained clinical conditions. J Urol 172:1242-1248. CrossRef Medline

Cruzblanca H, Koh DS, Hille B (1998) Bradykinin inhibits M current via phospholipase $\mathrm{C}$ and $\mathrm{Ca}^{2+}$ release from $\mathrm{IP}_{3}$-sensitive $\mathrm{Ca}^{2+}$ stores in rat sympathetic neurons. Proc Natl Acad Sci U S A 95:7151-7156. CrossRef Medline

Delmas P, Brown DA, Dayrell M, Abogadie FC, Caulfield MP, Buckley NJ (1998) On the role of endogenous G-protein $\beta \gamma$ subunits in $\mathrm{N}$-type $\mathrm{Ca}^{2+}$ current inhibition by neurotransmitters in rat sympathetic neurones. J Physiol 506:319-329. CrossRef Medline

Dickson EJ, Falkenburger BH, Hille B (2013) Quantitative properties and receptor reserve of the $\mathrm{IP}_{3}$ and calcium branch of $\mathrm{G}_{\mathrm{q}}$-coupled receptor signaling. J Gen Physiol 141:521-535. CrossRef Medline

Diniz BS, Teixeira AL, Machado-Vieira R, Talib LL, Gattaz WF, Forlenza OV (2013) Reduced serum nerve growth factor in patients with late-life depression. J Geriatr Psychiatry 21:493-496. CrossRef Medline

Dmitrieva N, Shelton D, Rice AS, McMahon SB (1997) The role of nerve growth factor in a model of visceral inflammation. Neuroscience 78:449459. CrossRef Medline

Donnerer J, Schuligoi R, Stein C (1992) Increased content and transport of substance $\mathrm{P}$ and calcitonin gene-related peptide in sensory nerves innervating inflamed tissue: evidence for a regulatory function of nerve growth factor in vivo. Neuroscience 49:693-698. CrossRef Medline

Falkenburger BH, Jensen JB, Hille B (2010) Kinetics of $\mathrm{M}_{1}$ muscarinic receptor and $\mathrm{G}$ protein signaling to phospholipase $\mathrm{C}$ in living cells. J Gen Physiol 135:81-97. CrossRef Medline

Ford CP, Wong KV, Lu VB, Posse de Chaves E, Smith PA (2008) Differential neurotrophic regulation of sodium and calcium channels in an adult sympathetic neuron. J Neurophysiol 99:1319-1332. CrossRef Medline

Friedel RH, Schnürch H, Stubbusch J, Barde YA (1997) Identification of genes differentially expressed by nerve growth factor- and neurotrophin3-dependent sensory neurons. Proc Natl Acad Sci U S A 94:12670-12675. CrossRef Medline

Garber SS, Hoshi T, Aldrich RW (1989) Regulation of ionic currents in pheochromocytoma cells by nerve growth factor and dexamethasone. J Neurosci 9:3976-3987. Medline

Gould HJ 3rd, Gould TN, England JD, Paul D, Liu ZP, Levinson SR (2000) A possible role for nerve growth factor in the augmentation of sodium channels in models of chronic pain. Brain Res 854:19-29. CrossRef Medline

Hefti FF, Rosenthal A, Walicke PA, Wyatt S, Vergara G, Shelton DL, Davies AM (2006) Novel class of pain drugs based on antagonism of NGF. Trends Pharmacol Sci 27:85-91. CrossRef Medline

Hempstead BL, Martin-Zanca D, Kaplan DR, Parada LF, Chao MV (1991) High-affinity NGF binding requires coexpression of the trk protooncogene and the low-affinity NGF receptor. Nature 350:678-683. CrossRef Medline

Hohenfellner M, Nunes L, Schmidt RA, Lampel A, Thüroff JW, Tanagho EA (1992) Interstitial cystitis: increased sympathetic innervation and related neuropeptide synthesis. J Urol 147:587-591. Medline

Jensen JB, Lyssand JS, Hague C, Hille B (2009) Fluorescence changes reveal kinetic steps of muscarinic receptor-mediated modulation of phosphoinositides and $\mathrm{K}_{\mathrm{V}}$ 7.2/7.3 $\mathrm{K}^{+}$channels. J Gen Physiol 133:347-359. CrossRef Medline

Jiang YH, Peng CH, Liu HT, Kuo HC (2013) Increased pro-inflammatory cytokines, C-reactive protein and nerve growth factor expressions in serum of patients with interstitial cystitis/bladder pain syndrome. PLoS One 8:e76779. CrossRef Medline

Jones S, Brown DA, Milligan G, Willer E, Buckley NJ, Caulfield MP (1995) Bradykinin excites rat sympathetic neurons by inhibition of $M$ current through a mechanism involving $B_{2}$ receptors and $G_{\alpha q / 11}$. Neuron 14:399_ 405. CrossRef Medline

Kasai M, Mizumura K (1999) Endogenous nerve growth factor increases the sensitivity to bradykinin in small dorsal root ganglion neurons of adjuvant inflamed rats. Neurosci Lett 272:41-44. CrossRef Medline

Kasai M, Kumazawa T, Mizumura K (1998) Nerve growth factor increases sensitivity to bradykinin, mediated through $\mathrm{B}_{2}$ receptors, in capsaicinsensitive small neurons cultured from rat dorsal root ganglia. Neurosci Res 32:231-239. CrossRef Medline

Kumar V, Mahal BA (2012) NGF: the TrkA to successful pain treatment. J Pain Res 5:279-287. CrossRef Medline

Lei S, Dryden WF, Smith PA (1997) Regulation of N- and L-type $\mathrm{Ca}^{2+}$ channels in adult frog sympathetic ganglion $\mathrm{B}$ cells by nerve growth factor in vitro and in vivo. J Neurophysiol 78:3359-3370. Medline

Levi-Montalcini R, Booker B (1960a) Destruction of the sympathetic ganglia in mammals by an antiserum to a nerve-growth protein. Proc Natl Acad Sci U S A 46:384-391. CrossRef Medline

Levi-Montalcini R, Booker B (1960b) Excessive growth of the sympathetic ganglia evoked by a protein isolated from mouse salivary glands. Proc Natl Acad Sci U S A 46:373-384. CrossRef Medline

Lewin GR, Rueff A, Mendell LM (1994) Peripheral and central mechanisms of NGF-induced hyperalgesia. Eur J Neurosci 6:1903-1912. CrossRef Medline

Lewis GP, Reit E (1965) The action of angiotensin and bradykinin on the superior cervical ganglion of the cat. J Physiol 179:538-553. Medline

Lindsay RM, Harmar AJ (1989) Nerve growth factor regulates expression of neuropeptide genes in adult sensory neurons. Nature 337:362-364. CrossRef Medline

Liu HT, Jiang YH, Kuo HC (2013) Increased serum adipokines implicate chronic inflammation in the pathogenesis of overactive bladder syndrome refractory to antimuscarinic therapy. PLoS One 8:e76706. CrossRef Medline

Longo G, Osikowicz M, Ribeiro-da-Silva A (2013) Sympathetic fiber sprouting in inflamed joints and adjacent skin contributes to pain-related behavior in arthritis. J Neurosci 33:10066-10074. CrossRef Medline

López-Domínguez AM, Espinosa JL, Navarrete A, Avila G, Cota G (2006) Nerve growth factor affects $\mathrm{Ca}^{2+}$ currents via the p75 receptor to enhance prolactin mRNA levels in GH3 rat pituitary cells. J Physiol 574:349-365. CrossRef Medline

Lutgendorf SK, Latini JM, Rothrock N, Zimmerman MB, Kreder KJ Jr (2004) Autonomic response to stress in interstitial cystitis. J Urol 172: 227-231. CrossRef Medline

Luther JA, Birren SJ (2006) Nerve growth factor decreases potassium currents and alters repetitive firing in rat sympathetic neurons. J Neurophysiol 96:946-958. CrossRef Medline

Luther JA, Birren SJ (2009) p75 and TrkA signaling regulates sympathetic neuronal firing patterns via differential modulation of voltage-gated currents. J Neurophysiol 29:5411-5424. CrossRef Medline

Marrion NV (1997) Control of M-current. Annu Rev Physiol 59:483-504. CrossRef Medline 
Mathie A, Bernheim L, Hille B (1992) Inhibition of N- and L-type calcium channels by muscarinic receptor activation in rat sympathetic neurons. Neuron 8:907-914. CrossRef Medline

McMahon SB, Bennett DL, Priestley JV, Shelton DL (1995) The biological effects of endogenous nerve growth factor on adult sensory neurons revealed by a trkA-IgG fusion molecule. Nat Med 1:774-780. CrossRef Medline

Orike N, Thrasivoulou C, Wrigley A, Cowen T (2001) Differential regulation of survival and growth in adult sympathetic neurons: an in vitro study of neurotrophin responsiveness. J Neurobiol 47:295-305. CrossRef Medline

Palumbo MA, Giuffrida E, Gulino FA, Leonardi E, Cantarella G, Bernardini R (2013) Nerve growth factor (NGF) levels in follicular fluid of infertile patients undergoing to in vitro fertilization (IVF) cycle. Gynecol Endocrinol 29:1002-1004. CrossRef Medline

Peeker R, Aldenborg F, Dahlström A, Johansson SL, Li JY, Fall M (2000) Increased tyrosine hydroxylase immunoreactivity in bladder tissue from patients with classic and nonulcer interstitial cystitis. J Urol 163:11121115. CrossRef Medline

Peleshok JC, Ribeiro-da-Silva A (2012) Neurotrophic factor changes in the rat thick skin following chronic constriction injury of the sciatic nerve. Mol Pain 8:1. CrossRef Medline

Peng WM, Maintz L, Allam JP, Raap U, Gütgemann I, Kirfel J, Wardelmann E, Perner S, Zhao W, Fimmers R, Walgenbach K, Oldenburg J, Schwartz LB, Novak N (2013) Increased circulating levels of neurotrophins and elevated expression of their high-affinity receptors on skin and gut mast cells in mastocytosis. Blood 122:1779-1788. CrossRef Medline

Pezet S, McMahon SB (2006) Neurotrophins: mediators and modulators of pain. Annu Rev Neurosci 29:507-538. CrossRef Medline

Plummer MR, Logothetis DE, Hess P (1989) Elementary properties and pharmacological sensitivities of calcium channels in mammalian peripheral neurons. Neuron 2:1453-1463. CrossRef Medline

Prado GN, Taylor L, Zhou X, Ricupero D, Mierke DF, Polgar P (2002) Mechanisms regulating the expression, self-maintenance, and signalingfunction of the bradykinin $B_{2}$ and $B_{1}$ receptors. J Cell Physiol 193:275286. CrossRef Medline

Ramer MS, Bradbury EJ, McMahon SB (2001) Nerve growth factor induces $\mathrm{P} 2 \mathrm{X}_{3}$ expression in sensory neurons. J Neurochem 77:864-875. CrossRef Medline

Rehak R, Bartoletti TM, Engbers JD, Berecki G, Turner RW, Zamponi GW (2013) Low voltage activation of KCal.1 current by $\mathrm{Ca}_{\mathrm{V}} 3-\mathrm{KCa} 1.1 \mathrm{com}-$ plexes. PLoS One 8:e61844. CrossRef Medline

Reinhardt RR, Chin E, Zhang B, Roth RA, Bondy CA (1994) Selective coexpression of insulin receptor-related receptor (IRR) and TRK in NGFsensitive neurons. J Neurosci 14:4674-4683. Medline

Rosenbaum T, Castañares DT, López-Valdés HE, Hiriart M (2002) Nerve growth factor increases L-type calcium current in pancreatic beta cells in culture. J Membr Biol 186:177-184. CrossRef Medline

Rothberg BS (2012) The BK channel: a vital link between cellular calcium and electrical signaling. Protein Cell 3:883-892. CrossRef Medline

Rukwied R, Weinkauf B, Main M, Obreja O, Schmelz M (2013) Inflammation meets sensitization: an explanation for spontaneous nociceptor activity? Pain 154:2707-2714. CrossRef Medline

Sarchielli P, Alberti A, Floridi A, Gallai V (2001) Levels of nerve growth factor in cerebrospinal fluid of chronic daily headache patients. Neurology 57:132-134. CrossRef Medline

Schechter AL, Bothwell MA (1981) Nerve growth factor receptors on PC12 cells: evidence for two receptor classes with differing cytoskeletal association. Cell 24:867-874. CrossRef Medline

Schnegelsberg B, Sun TT, Cain G, Bhattacharya A, Nunn PA, Ford APDW,
Vizzard MA, Cockayne DA (2010) Overexpression of NGF in mouse urothelium leads to neuronal hyperinnervation, pelvic sensitivity, and changes in urinary bladder function. Am J Physiol 298:R534-R547. CrossRef Medline

Sharma N, D’Arcangelo G, Kleinlaus A, Halegoua S, Trimmer JS (1993) Nerve growth factor regulates the abundance and distribution of $\mathrm{K}^{+}$ channels in PC12 cells. J Cell Biol 123:1835-1843. CrossRef Medline

Shu X, Mendell LM (1999) Nerve growth factor acutely sensitizes the response of adult rat sensory neurons to capsaicin. Neurosci Lett 274:159162. CrossRef Medline

Stein AT, Ufret-Vincenty CA, Hua L, Santana LF, Gordon SE (2006) Phosphoinositide 3-kinase binds to TRPV1 and mediates NGF-stimulated TRPV1 trafficking to the plasma membrane. J Gen Physiol 128:509-522. CrossRef Medline

Straub RH, Wiest R, Strauch UG, Härle P, Schölmerich J (2006) The role of the sympathetic nervous system in intestinal inflammation. Gut 55:1640 1649. CrossRef Medline

Suh BC, Hille B (2002) Recovery from muscarinic modulation of M current channels requires phosphatidylinositol 4,5-bisphosphate synthesis. Neuron 35:507-520. CrossRef Medline

Toma H, Winston J, Micci MA, Shenoy M, Pasricha PJ (2000) Nerve growth factor expression is up-regulated in the rat model of $\mathrm{L}$-arginine-induced acute pancreatitis. Gastroenterology 119:1373-1381. CrossRef Medline

Ugolini G, Marinelli S, Covaceuszach S, Cattaneo A, Pavone F (2007) The function neutralizing anti-TrkA antibody MNAC13 reduces inflammatory and neuropathic pain. Proc Natl Acad Sci U S A 104:2985-2990. CrossRef Medline

van der Wal J, Habets R, Várnai P, Balla T, Jalink K (2001) Monitoring agonist-induced phospholipase $\mathrm{C}$ activation in live cells by fluorescence resonance energy transfer. J Biol Chem 276:15337-15344. CrossRef Medline

Vivas O, Castro H, Arenas I, Elías-Viñas D, García DE (2013) PIP ${ }_{2}$ hydrolysis is responsible for voltage independent inhibition of $\mathrm{Ca}_{\mathrm{v}} 2.2$ channels in sympathetic neurons. Biochem Biophys Res Commun 432:275-280. CrossRef Medline

Yoshimura N, Bennett NE, Hayashi Y, Ogawa T, Nishizawa O, Chancellor MB, de Groat WC, Seki S (2006) Bladder overactivity and hyperexcitability of bladder afferent neurons after intrathecal delivery of nerve growth factor in rats. J Neurosci 26:10847-10855. CrossRef Medline

Zahn PK, Subieta A, Park SS, Brennan TJ (2004) Effect of blockade of nerve growth factor and tumor necrosis factor on pain behaviors after plantar incision. J Pain 5:157-163. CrossRef Medline

Zaika O, Tolstykh GP, Jaffe DB, Shapiro MS (2007) Inositol triphosphatemediated $\mathrm{Ca}^{2+}$ signals direct purinergic $\mathrm{P} 2 \mathrm{Y}$ receptor regulation of neuronal ion channels. J Neurosci 27:8914-8926. CrossRef Medline

Zhang H, Craciun LC, Mirshahi T, Rohács T, Lopes CM, Jin T, Logothetis DE (2003) PIP 2 activates KCNQ channels, and its hydrolysis underlies receptor-mediated inhibition of $\mathrm{M}$ currents. Neuron 37:963-975. CrossRef Medline

Zhang X, Huang J, McNaughton PA (2005) NGF rapidly increases membrane expression of TRPV1 heat-gated ion channels. EMBO J 24:42114223. CrossRef Medline

Zhang YH, Vasko MR, Nicol GD (2002) Ceramide, a putative second messenger for nerve growth factor, modulates the TTX-resistant $\mathrm{Na}^{+}$current and delayed rectifier $\mathrm{K}^{+}$current in rat sensory neurons. J Physiol 544: 385-402. CrossRef Medline

Zhu W, Galoyan SM, Petruska JC, Oxford GS, Mendell LM (2004) A developmental switch in acute sensitization of small dorsal root ganglion (DRG) neurons to capsaicin or noxious heating by NGF. J Neurophysiol 92:3148-3152. CrossRef Medline 